University of San Diego

Digital USD

Theses

Theses and Dissertations

Summer 8-7-2018

\title{
Professional Heartbreakers: Male Entertainers and the Divide Between Popular Culture and History in Japan
}

Meradeth Lin Edwards

University of San Diego

Follow this and additional works at: https://digital.sandiego.edu/theses

Part of the Asian History Commons, and the History of Gender Commons

\section{Digital USD Citation}

Edwards, Meradeth Lin, "Professional Heartbreakers: Male Entertainers and the Divide Between Popular Culture and History in Japan" (2018). Theses. 31.

https://digital.sandiego.edu/theses/31

This Thesis: Open Access is brought to you for free and open access by the Theses and Dissertations at Digital USD. It has been accepted for inclusion in Theses by an authorized administrator of Digital USD. For more information, please contact digital@sandiego.edu. 
UNIVERSITY OF SAN DIEGO

\title{
Professional Heartbreakers: Male Entertainers and the Divide Between Popular Culture and History in Japan
}

\begin{abstract}
A thesis submitted in partial satisfaction of the requirements for the degree of Master of Arts in History
\end{abstract}

by

Meradeth Lin Edwards

\author{
Thesis Committee \\ Yi Sun, Ph.D., Chair \\ Michael Gonzalez, Ph.D.
}


The Thesis of Meradeth Lin Edwards is approved by:

Thesis Committee Chair

Thesis Committee Member

\author{
University of San Diego
}

San Diego

2018

ii 
Copyright 2018 Meradeth Lin Edwards

Limitations: No part of this document may be reproduced in any form without the author's prior written consent for a period of three years after the date of submittal.

\section{Meradeth Lin Edwards}


Dedicated to my American parents, who were undoubtedly the most enthusiastic fans of this work and are patient with my free spirit, and my Japanese parents, who instilled in me a great love of their culture, history, and lifestyle. 


\section{ACKNOWLEDGMENTS}

I would first like to acknowledge and thank my thesis committee, Dr. Sun and Dr. Gonzalez, who were both incredibly patient and supportive of my work with Japanese culture and history. This was not at all an easy project for me and I felt many times that I did not have the strength or potential to finish it at all. However, Dr. Gonzalez always went the extra step to keep a steady tab on my own well-being. He was also always enthusiastic about the project despite having little grounding in Japanese history. It was very refreshing to teach my own professors. Dr. Sun was always accommodating with my choice in topic, and I simply must thank her for her "Women in East Asia" course, as much of my materials came from that class. Through the eyes of feminism I was able to better understand a world where anyone who was not a strong, aggressive male was considered "less".

Very often I find myself the odd person out among my colleagues with my interest in the history of prostitution. Male prostitutes in Japan specifically is not a topic that has been touched upon very often. I have a keen interest in the lives of female entertainers, escorts, and prostitutes but I was also very interested in how the male version of that "pink world" came about and how something that began as entertainment for males shifted into an expression of sexuality for females in the contemporary world. I must absolutely acknowledge the historians, writers, and even bloggers, who have shared their experiences and their studies from Japan. I am grateful that they have traveled to these places and spoken to these men as it was not something I was able to do myself at this time. I hope that in the future more works will be translated and written, and the voices lost within Japan's history will be heard. 
Table of Contents

I: Introduction

II: A History of Male Love

III: The Floating World of Fiction and the Kabuki Craze __ 32

IV: Pink Japan _ 49

V: Men in Print __ 64

VI: Boys' Love

VII: Conclusion __ 80

Bibliography __ 83 


\section{CHAPTER 1: INTRODUCTION}

The colorful social culture of Japan is hardly a secret to the rest of the world. Whether viewed in admiration or confusion, the average person has seen a school or maid girl, funky street fashions, or television shows, games, and movies that are Japanese in origin. However, one phenomenon in particular has been slow to surface despite its deep roots in Japan's history: the host club and male entertainers. Host and hostess clubs are exclusive establishments that provide companionship to men and women for a hefty fee. Clubs for either gender were practically invisible when they began, with female host clubs emerging in the 1920s and male clubs four decades later. ${ }^{1}$ The clubs then skyrocketed to popularity in the twenty-first century. Although it is a business that caters primarily to a female clientele in the present, both in fiction and real life, that has not always been the case. In fact, men have been the most common customers of this service throughout history. The concept of a subservient male thoroughly challenges strict Japanese gender roles, thus undermining the importance of these men's place in Japanese tradition. It is much easier to accept a comic book or TV drama centering on male entertainment, where this cultural tradition is found on a public level. I argue that men have been used for entertainment and personal companionship throughout Japan's illustrious history. Understanding who these entertainers were, why they entertained, and how the entire ideal of "buyable romance" came about is an important step to understanding societal norms in Japan and why they are so strict even in the contemporary world.

Akiko Takeyama, "Commodified romance in a Tokyo host club," in Genders, Transgenders and Sexuality in Japan, edited by Mark Mclelland and Romit Dasgupta (New York: Routledge, 2005), 200215. 
Traveling to Kyoto, Japan today would present the opportunity of meeting a geisha, a beautiful, demure woman dressed in traditional Japanese kimono, face white, lips red, and sleek black hair adorned with intricate ornaments. Perhaps she is hiding behind a fan or carrying a shamisen ${ }^{2}$. This image is popularly associated with Japan, whether a geisha's actual duties are understood or not. What is not commonly known is that the first geisha were actually male. They were originally called taikomochi, which means "drum bearer", because most of them carried a small hand drum to their performances. There are records of taikomochi as early as the thirteenth century, several centuries before female geisha ever appeared. Men were known to court and/or purchase the company of males (boys, usually) for centuries before taikomochi. Some sources even suggest that the custom was introduced in the early ninth century $\mathrm{CE}^{3}$, which will be explained later in my thesis. For now, we can liken male entertainers to geisha, since that is the most recognizable image to a general audience. Like their female counterparts, taikomochi danced, sang, and instead of acting on a stage, they mingled with their clients telling jokes and serving them drinks. ${ }^{4}$ A taikomochi was like a jester in Western terms. It was for them that the term "gei-sha-" literally "arts person," was coined. When women were introduced to the profession, they were referred to as geiko, or "arts child"; "ko" is an endearing title still attached to girls' names today.

In modern times, we may assume that paying for companionship included engaging automatically in sexual acts with them, but this was not always the case in Edo, Japan. In fact, it is offensive to even suggest that these entertainers today are also

A shamisen is a stringed instrument often used in traditional Japanese music.

3 See Tsuneo Watanabe and Junichi Iwata, The love of the samurai: a thousand years of Japanese homosexuality (London: GMP Publishers, Ltd., 1989).

4 Lesley Downer, Geisha: The secret history of a vanishing world (London: Headline Book Publishing, 2000), 81 . 
prostitutes. Even for taikomochi in the Middle Ages it may have come off as troublesome or offensive to either party, especially since it involved men buying the service of other men. This company was not purchased for intimacy but for conversation and companionship, the patrons would say, because a man could not expect to get these things from his subservient wife. The role of a wife was very limited. She would raise the children and maintain the household but was not considered an adequate conversationalist. However, it was the role of a companion to please his or her clients. The taikomochi would "treat the customers like kings. Whatever they ask, they can't say No." ${ }^{\circ}$ Therefore, sleeping with a client could also be considered very normal and was not questioned if the price was paid. The reason for this somewhat contradictory etiquette once again had to do with machismo, in that sleeping with or romancing another man was not "manly, especially for the 'receiver'," and should never be spoken of openly. Regardless, there were known bouts of violence and betrayal between friends, family, and fellow countrymen in this period over the affections of pretty men, and often these displays were extremely public.

Some men would engage in sexual acts with a male geisha because being with a man was clearly different than being with a woman which could in turn add excitement to an otherwise dull married life. Marriages were considered "dull" because they were often (and sometimes still are) arranged and thus without love. The man would work and provide for the family and the woman would serve him and provide him with sons. Thus, the romance and close camaraderie associated with marriage today did not exist in most cases. Therefore, men would seek company elsewhere, and being treated according to a man's personal fantasy could be both addicting and dangerous. Men lost $5 \quad$ Ibid, 84. 
their families, their wives, and their money after paying too much for a man's company and were themselves forced to become taikomochi in order to pay off all the debts. This is paralleled almost exactly by the contemporary prostitution culture in Japan. Men and women who indulge too often in prostitution are forced to become hosts or prostitutes themselves, and even then they sometimes cannot get rid of the urge to visit a club or call boy/girl service. Prostitution is considered an addiction, and its prevalence questions a society held together by strong gender roles. These gender roles are enforced by the government. The following political facts are necessary to know in understanding how a host club or any kind of "underworld" business serves as a getaway or a safe haven to many of its workers and clients.

Japan has been a constitutional monarchy since 1889. And while the Constitution of 1947, written after the country's surrender at the end of World War II, has stripped the divine aura from the emperor, who has since been less of an active leader and more of a figurehead, he remains a symbol of the Japanese state. Long before the Meiji era (18681912), power was first held by the shogun, an important military leader. It is now held by the Prime Minister and the Diet, with elected politicians in two houses: the House of Representatives and the House of Councilors. Sovereignty meanwhile resides with the people. ${ }^{6}$ Two prominent political parties are represented in the Diet, but it has been a struggle for the more liberal parties to gain power within the Houses. Despite being called "liberal", the conservative Liberal Democratic Party (LDP) has ruled Japan for a long time. The LDP remains tied to old traditions born from political ideals that shaped Japan centuries ago. The Democratic Party of Japan (DPJ), however, does feel that

6 "The Constitution of Japan," House of Councilors in the National Diet of Japan, accessed May 16, 2013, http://www.sangiin.go.jp/eng/law/index.htm. 
many things in Japan are no longer properly represented. The Party's view on Japan's status quo is as follows:

Today's Japan is no longer responding to the changing times. This is because bureaucracy-led protectionism and conformity and the structure of collusion have reached a dead end. Before Japan enters an age of fewer children and an aging population in the early 21 st century, we must overthrow the ancien régime locked in old thinking and vested interests, solve the problems at hand, and create a new, flexible, affluent society which values people's individuality and vitality. ${ }^{7}$

This statement was published on the official DPJ website in April 1998. Unfortunately, it is difficult to make these desired changes for a "younger" Japan when the Party cannot hold power within the Houses. Eleven years after its founding, the DPJ won most of the chairs within the Diet in the election of 2009, but by 2012 the LDP won out again. The difficulties of liberal parties have endured for decades, but from the past fifteen years alone it is plain to see that Japan has been stubborn for change.

Japan is a relatively conservative country, and any minority is deemed unnatural and therefore either discriminated against or excluded. Most of these "unnatural" topics, - such as women's movements, AIDS, homosexuality, and "men disaffected with notions of hegemonic masculinity," have little to no outlet or representation in Japan. ${ }^{8}$

Therefore, drawing attention to the history, practice, or existence of men who sell their company, including the origins of geisha, is highly discouraged. Consequently, scholars have not made significant efforts to interpret male roles in Japanese sex culture. There are very few sources with a substantial amount of information about this topic. Even

7 "Our Basic Philosophy - Building a Free and Secure Society -," The Democratic Party of Japan, accessed May 16, 2013, http://www.dpj.or.jp/english/about_us/philosophy.html.

8 Nanette Gottlieb and Mark McLelland, Japanese Cybercultures, ed. Nanette Gottlieb and Mark Mclelland (London: Routledge, 2003), 11. 
those who write articles on the subject, such as anthropologist Akiko Takeyama, admit to focusing primarily on female hostesses, clubs for women, and the impact of this subculture on feminism and women's place in Japanese society. ${ }^{9}$ This topic is easier to explore due to its ties to feminism. Many women feel liberated from their expected roles by controlling men through fulfilling male sexual fantasies. It is a double-edged sword, however, in that "serving men" is expected and "natural."

My work, by examining the existence of sex clubs, addressing a topic that is often overlooked, adds to the study of gender and sexuality in Japan. It envelops women and girls who are not free to express and explore their own sexualities. This study also includes men who do not conform to the expectation of the male role in Japan and thus are also without many social or emotional outlets. Men who did not fit the traditional mold turned to prostitution and printed fantasies. The trend has shifted to include women. That shift will be explained in a later chapter.

Author Veronica Chambers discusses host clubs from the point of view of the female role, only with women as customers. While the clubs were once considered an "anomaly," she writes, now they are quite popular because women are "making more money" and "enjoying more independence." 10 There is little information on the male role in club culture and how it may contribute to the slow departure from rigid societal norms. When a woman visits a host club as a customer, she goes there to relax after work or seek an outlet for stresses in her life by seeking the company of a beautiful man. She will pay a base "door fee" and then for all the drinks she consumes that evening in return for her chosen host's company. He, and sometimes other hosts without clients, will

9 Akiko Takeyama, "Commodified romance in a Tokyo host club," in Genders, Transgenders and Sexuality in Japan, edited by Mark Mclelland and Romit Dasgupta (New York: Routledge, 2005), 200215.

10 Veronica Chambers, Kickboxing Geisha (New York: Free Press, 2007), 141. 
compliment her, serve her drinks, sing with her, listen to stories of the stresses of her everyday life, or just about anything else his customer desires, short of any sexual contact. Engaging in sexual acts is not only illegal but considered an "end game" for hosts. The male hosts' intent is for the women to more or less fall in love with them and to therefore keep coming back to the club. However, getting intimate with female clients would eliminate the need for them to keep coming back. Of course, sexual contact does happen from time to time, albeit "unofficially."

In a pictorial work about sex clubs in Japan by Joan Sinclair, host clubs are only featured for eight pages with very little text. The two-page spread is an image of a female customer engaging in a game at one of the clubs in Tokyo, with a caption by a male host talking about his customers - girls who are also in the host club business. ${ }^{11}$ The host does, however, mention that talking about work between customer and client is not allowed. No explanation on the topic is provided in this book. The most likely reason is that when a customer comes to a host club, he or she does not want to talk about work. The customers want to go into a host club and enter a fantasy world to take their minds off their everyday lives. The hosts' job is to indulge in the fantasy to make the customer happy. Also, many clients who are prostitutes do not enjoy their work and would rather not be reminded of it.

The historian Nicholas Bornoff briefly examines the sexuality of men in Japan, which includes hosts in both heterosexual and homosexual clubs, as well as special "fetish" based clubs such as those for cross-dressers. One of his chapters provides an indepth English translation of the descriptions of Japanese men in the sex industry. Bornoff, like myself, believes that while the sexual culture of Japan is largely female- 
centric, the changing roles and interests of men are also extremely important. ${ }^{12}$ This is definitely true as the youth of Japan gradually makes a shift to the liberal "left," and the usage of internet forums is becoming far more popular today than in the 1990 s and even early 2000s. With the internet, Japanese men and women can speak to people all over the world. They can meet other men and women like themselves, be they people suffering from AIDS, or gay, or simply fans of the same comics and books. The internet, of course, also provides a lot of literature on a vast number of topics to which many Japanese youths otherwise have no access to. The Internet helps a young person question his/her sexuality or identity by providing information on the roles and interests of men and women alike all over the world.

Scholars such as Gregory Leupp, Tsuneo Watanabe, and Junichi Iwata give valuable insights into the history of homosexuality in Japan and the social custom of courting and engaging male prostitutes. This history is invaluable to the study of gender roles, male prostitution, and why fictional romance has always been extremely popular and frowned upon at the same time. Gary Leupp writes about the history of priests and samurai, who attend Japanese theater where the concept of "hosts" was born. ${ }^{13}$ Watanabe and Iwata summarize much of the same. However, they also present excerpts of popular stories from the scope of time covered in their book: The love of the samurai: a thousand years of Japanese homosexuality. Certainly much can be lost in translation but even in English a reader can easily immerse in the world of male entertainment. Iwata and Watanabe's study then ties history and popular stories together.

Informal "studies" of male hosts by American bloggers are also gaining

12 Nicholas Bornoff, Pink Samurai: Love, Marriage, and Sex in Contemporary Japan (New York: Pocket Books, 1991).

13 Gary P Leupp, Male Colors: The Construction of Homosexuality in Tokugawa Japan (University of California Press: Berkely, CA, 1995). 
popularity, with the emergence of documentaries and vloggers ${ }^{14}$ such as Chris Gen who presents filmed tours of Japanese red light districts and interviews actual hosts. Other blogs based upon learning about Japanese culture, such as those contained in Tofugu.com, also make attempts at solving the mystery of the world of paid male companions through humorous articles, accompanied by pictures and videos. They can, however, appear contradictory when written by different authors, so any reader should understand that these sources cannot always be considered reliable. For example, one contributor to Tofugu.com called "John" wrote an article on the link between 'male geisha' and male hosts, while the contributor "Nick" 15 stated that the one difference between the time of geisha and now is the "inclusion of men as servers in Japan's night time industry." geisha" existed long before female geisha, while Nick's states that men in the business are a relatively new development. The second point of view is misinformed, though any reader without sufficient knowledge of the topic would not know so.

There are currently many blogs and videos maintained by non-Japanese that are easily accessible with a simple search engine. Topics range from traditional practices like tea ceremony, to what it is like being homosexual in Japan, to how to buy personal hygiene products as a foreigner in Japan. It is clear that by using the internet, Japanese minority groups are catching the attention of others who can give them the voice that mainstream Japanese do not.

On the other hand, it is not difficult at all to encounter male hosts, prostitutes, or

14 "Vlogging" and associated forms are colloquial terms that come from "video blogging", a form of social media made popular through websites such as YouTube.

15 Using an alias on a blog, no matter how professional, is quite common. There is no more information about these contributors as they wish to remain anonymous.

16 “Japan's Fantasy Girls - Geisha to Maid Cafes," Tofugu, accessed March 6, 2013, http://www.tofugu.com/2010/07/27/japans-fantasy-girls-geisha-to-maid-cafes/. 
actors in fictional materials in Japan, as seen in many popular anime and manga. ${ }^{17}$

Generally, these fictional stories are for female audiences in the shoujo ${ }^{18}$ genre, that is, romance stories specifically written for enjoyment by girls in their preteens to twenties. The "cool" host figure is also extremely popular in "Boys' Love"19 comics, which is a genre written mostly by women for women about homosexual relationships between men. Originally however, homoerotic literature and art targeted other males. Although many comics and television shows are highly fictionalized, authors such as Kano Miyamoto have published stories that are quite true to life. ${ }^{20}$ Manga became popular in the mid-twentieth century, but fictional works written for men about sex have been in existence for centuries. The very first instance of such fiction can be traced back to the late fifteenth century. At least, that was when the term shuudou was first used, ${ }^{21}$ and shuudou became a genre encompassing stories and novels about men in love. In some cases, it is easier to learn about male prostitutes in Boys' Love comics or shuudou than through a historical study because the stories center on men who fall outside of societal norms. The female fans who read these comic books are considered abnormal as well. Men who indulge too often in shuudou novels are also anomalies. In the contemporary world, often the girls become fans because the stories are so different from the strict societal rules they are made to follow.

Women, tired of being dismissed, are becoming more independent in Japan. This

17 Anime is the Japanese term for animated movies and television. It is a borrowed English word, shortened from "animation". Manga is the Japanese term for graphic novels or comic books that come in a variety of genres and are usually published monthly by chapters and then produced in a tankouban, or bound copy of the entire story sold much like a novel.

18 Lit. "girl"

19 Boys' Love is a term often officially shortened as simply "BL".

20 Kano Miyamoto is a mangaka or an author of manga. She has ongoing serials titled "Rules" and "Walker" that both contain heavy instances of male prostitution and references to the red light districts in Tokyo. Her comics also often relate to how difficult it is to find acceptance as a man who is either a sex worker or homosexual or both.

21 Watanabe \& Iwata, 48. 
is by no means an issue that should be glossed over or set aside. However, it is as if men who do not fit the social norm of a strong, manly family leader do not exist. In traditional Japanese culture and even up to the present, a man is generally the dominant figure and a woman should be submissive and obey the man at all times. Starting from before even the Edo period, the man of the house was considered the bread-winner and made all important decisions. The woman may have been in charge of household affairs, but it was for the sake of her husband and children. If she was unmarried she must listen to her father and get married as soon as possible. This was the basic frame for how men and women were expected to behave in Japan. These traditional models are being challenged by young people who are tired of being suffocated by outdated ideals. Nonetheless, today men are still the primary supporter of the family. The husband still makes every important decision for the family. Until very recently, if a woman was not married by the age of 25 , she was considered a "stale Christmas cake" or an unmarriable spinster. For years, many women did not pursue an education beyond high school and got married as soon as possible instead. Today, women who are in higher positions at their jobs are still often treated as secretaries, expected to serve the men coffee and other such tasks regardless of her education or merits. It is worth noting, however, these behaviors are being increasingly challenged by the younger generation.

Like their counterparts elsewhere in the world, Japanese "minority" men and women long to express themselves and be represented properly by their society. Host men, too, are a part of this voiceless group that is not presently defined by Japanese culture. These men and women are not considered equal minorities. Women are still considered below even the most outcast groups of men, but male entertainers are considered very low as well. Their existence has always been highly secretive and 
guided by strict rules to keep them secret, so it has become very difficult to know anything about them.

The geisha, though considered to be dying out, are a proud part of Japanese history, but the fact that it began with men is not. Plenty is known about the women who purchase the company of young, beautiful men for companionship as a way to escape their reality, but the men who provide this fantasy getaway for them remain a mystery. With host clubs becoming more and more popular in Japanese society, and thus drawing the attention of the Western world, it is becoming impossible to ignore these men.

The purpose of this study is to reveal more about the secret world of host clubs and the men who work in them, thus challenging the perception of the social and gender norms within Japan. The reasons as to why it is more socially acceptable to talk about these men in completely fictional contexts, will also be studied. Knowing why young men become hosts will help in understanding how men in the sex industry challenge Japanese traditions. There has been a large gap between literature surrounding men in the sex industry. Why there is representation through fictional media but rarely elsewhere will also be examined.

Naturally the history of male entertainment will be laid out in the fullest detail possible, starting with Buddhist priests and their relationships with their acolytes, the likely origin of the entire business of the male entertainment business. This summation will be followed by an examination of the strong, brotherly bond between samurai and their pages. Finally, I will look at the explosion of male actor popularity and how this custom, along with governmental interference with the way the theater was allowed to work, evolved into special clubs made just for the purchasing of male company and male sex. 
Because most sources on the topic in a contemporary setting only contain limited portions specifically on the men in these pink businesses, ${ }^{22}$ a variety of materials will be used, including books, articles, documentaries, and interviews. In order to gain a true sense of the divide between historical and popular culture, some fictional materials will also be used. Beginning with the history of male companionship in Japan, its transformation into a woman's profession, and its inception through popular culture and the Japanese "underworld," the study will present a clearer picture of these men and their representation in Japan today. This idea of course also includes why this representation has moved from male audiences to female audiences. The ideal conclusion will be that this gap between popular culture and history will be bridged so this topic may be further studied. Although perhaps the reason that the acceptance of this culture has shifted so much will never find a clear explanation.

${ }^{22}$ Sex shops that sell prostitution, pornography, or other adult-oriented goods are referred to as "Pink" (or pinku ) in Japan. This term will be used interchangeably with the sex industry. 


\section{CHAPTER 2: A HISTORY OF MALE LOVE}

"There is no crime, large or small, that cannot be traced to the lust that lies hidden beneath its surface."

$$
\text { — Sawada Junjirou }{ }^{23}
$$

The varying claims of the origin and evolution of Japanese men paying for the company of other men warrant a great deal of academic inquiry. In this chapter I will briefly go over historical events and texts that directly relate to the changing idea of buying male companionship and how it is linked to the contemporary host man.

As mentioned previously, male entertainers actually existed long before females were even considered appropriate companions outside of marriage. The taikomochi were jester-like entertainers for men known from the $12^{\text {th }}$ century. However, Japan's long history of male companionship had originated even centuries before that. As Nicholas Bornoff states, "More is known about the artistic and cultural accomplishments of the various courts during the ages or war than about their erotic pleasures." ${ }^{24}$ I would argue that the traditions of keeping male companionship, for men and women, is part of the cultural history of Japan.

Japanese priests, and later the samurai class, enjoyed the company of other men or boys in relationships very similar to the same-sex romancing that occurred in ancient Greece. There is a certain resemblance in the relationship between samurai and their companions to the "etiquette" of other indigenous historical archetypes and "homoerotic love in particular." ${ }^{25}$ Although samurai relationships were based mainly on martial arts,

23 Sawada Junjirou, “Seiyoku hanzai”, (kindai no kekkonsha, 1923), 1.

24 Bornoff, 147.

25 Aleardo Zanghellini, “Boys' Love in Anime and Manga: Japanese Subcultural Production and its End Users” Journal of Media and Culutral Studies 23, no. 3 (June 2009): 285. 
some older men did establish intimate bonds with their male retainers. Some also purchased the company of prostitutes, some of whom were young males.

There is a myth about the origins of homosexuality in Japan, that is, the Buddhist monk Kukai, posthumously known as Kobo Daishi, introduced the custom in $806 \mathrm{CE}$, after returning from his travels in China. Therefore, it is often believed that homosexuality was a "Chinese custom." 26 The Japanese word for male eros, nanshoku, is even derived from the same characters used in the Chinese word, nanse. ${ }^{27}$ It is a popular "origin story", but its veracity is impossible to determine. Kobo Daishi did return from China in the $9^{\text {th }}$ century, but it is unknown if he was responsible for bringing same-sex relations in any way to Japan's culture. What makes the story less convincing is that a "mytho-historical" text entitled Kojiki that supposedly describes male sex was completed in 712 CE. Junichi Iwata writes that the first mention of homosexual activity is in a work titled Nihongi, where an Empress of China visited and described something that Iwata translated as the sin of homosexuality. However, since the Empress used an ancient word that's meaning is unclear, such a translation is up for debate. The first clear reference to homoerotic relationships does favor the Kobo Daishi myth as it appeared in a text written in $985 \mathrm{CE} .{ }^{28}$ Called the Oujouyoushuu, the text was a Buddhist philosophy book that proscribed against homosexuality.

During this early period, grown males would find company in both females and male youths because they were equally considered "other" from an adult man. They were, however, also very different from one another and not at all considered equal. ${ }^{29} \mathrm{~A}$

26 Watanabe \& Iwata, 31

27 In this case, "nan" in both languages translates as "male" and is written the same way in both languages. This is often the case between the two languages, although they do not always share the same pronunciation.

28 Leupp, 11.

29 Pflugfelder, 35. 
youth was still male and therefore regarded completely differently from a female regardless of her age. In fact, these boys were referred to as erotic objects with the word wakashu. Although it literally translates as "young people," it was understood as being limited to males only. Furthermore, as I will discuss, the relationship between a grown man and youth was considered far deeper and very complex. A wakashu was a lover who was not defined by his biological sex but by his age. He was "a male no longer a child but not yet a full grown man", and also a "gender that one was likely to grow out of." ${ }^{30}$ It was understood that being wakashu was a temporary state.

Usually once a boy reached a specific age, perhaps late teens to early twenties, he became a man and was expected to act as such, leaving all of his passive characteristics and mannerisms behind. Naturally there were many exceptions to this depending on the individual relationships, but the "correct" way was for the youthful ways to end. Still, young boys and girls were in their own ways considered proper company as long as one did not indulge in them very often. The inclusion of boys as company for men is referenced in numerous texts of the Edo period, such as this haiku written by Matsuo Bashou $^{31}$ :

Ume yanagi sazo

Wakashu kana

Onna kana.

Plum or willow,

30 JamesWelker, "Beautiful, Borrowed, and Bent: 'Boys' Love as Girls' Love in Shoujo Manga.” Journal of Women in Culture and Society (2006): 854-5.

31 Matsuo Basho (1644-1694) is recognized as the most famous Japanese poet of the Edo era. He is known to be greatest master of haiku, which is a famous style of poetry that remains popular today. Haiku are short lyrical poems that consist of 3 lines and 17 on (phonetic syllables) written 5-7-5 respectively. Although his haiku work is internationally renowned, he personally considered his strength to be in renku. Renku was a style of poetry that served as the haiku's predecessor. They were short, linked verses that were often witty or vulgar in content. 
Wakashu

Or woman? $?^{32}$

This poem refers to women and wakashu as completely separate objects. The comparison of a willow to a plum is the equivalent of comparing oranges to apples in the western world. In the haiku both are acceptable choices, but the implication of the text at the time it was written was that the wakashu was the obvious answer, poking fun at the men who indulged in homosexual relationships.

Whether or not there is truth to the Chinese "origin" of homosexuality in Japan, these relationships were very popular, especially in Buddhist monasteries where there were acolytes or apprentices of monks known as chigo. Once the chigo was grown and properly initiated, he would become a monk like his brothers ${ }^{33}$. Before he became a man and was introduced officially as a monk, the acolytes had their own customs and rituals. During the medieval period, they would shave their eyebrows, powder their faces, and dress in female attire for their monk masters. Other customs included blackening their teeth, penciling in their shaved eyebrows, sporting "girlish" hairstyles, and wearing other kinds of cosmetics. These practices made them appealing because they looked feminine. There were two reasons for these practices. The first was that the chigo represented beauty in daily life and ritual, and the second was that they were servants and often lovers of the older monks. ${ }^{34}$ What made these boys even more appealing than their female counterparts was that the personality and mannerisms of the chigo remained

32 Gregory M. Pflugfelder, Cartographies of Desire: Male-Male Sexuality in Japanese Discourse 16001950 (University of California Press: Berkely, CA, 1999), 35.

33 Monks and acolytes within the same monastery were considered brothers.

34 JR Brown. "1000 Years of Pretty Boys" August 25, 2010. http://www.hoodedutilitarian.com/2010/08/1000-years-of-pretty-boys/, October 20, 2015. 
strictly masculine..$^{35}$ It is important to point out that during no part of the Edo era was femininity in itself ever praised. Women were increasingly derided, and men focused on an "ultra-masculine exaltation of homosexuality." ${ }^{36}$ Men who were too flamboyant or feminine were (and are today) referred to as okama, the word for a cooking pot for rice that later came to symbolize the anus. This mentality, much like the existence of taikomochi, has been warped or erased over time, leading to assumptions of the opposite: that men were attracted to other men who behaved in a feminine way.

In the eighth century CE, Japan moved its capital from Nara to Kyoto, and the government underwent many changes. The reforms affected every aspect of Japanese life, including religion. Japanese Buddhism had insisted upon the "inherent evil and defiling nature" of women, ${ }^{37}$ who had to endure the "five obstacles" (goshou ) and "three obediences" (sanjuu ) of Buddhism. Women were also considered "evils" because they were incapable of achieving enlightenment, could result in offspring and/or karmic attachments for a man, and were not temporary pleasures as youths were ${ }^{38}$. While these proclamations about women are now thought to be a type of strategy to discourage monks from sexual relations, they backfired when the monks found other means of entertaining themselves: with males. The failure was even further exacerbated when monks were moved to monasteries in the mountains or other areas where women were completely banned. ${ }^{39}$

Additionally, in Buddhism, desiring the company of one's own gender is considered a worldly temptation, but the real danger is thought to be in male-female

\footnotetext{
35 Leupp 26.

Bornoff, 147.

Ibid., 38.

Pflugfelder, 74.

Leupp, 38.
} 
sexual pleasure due to the possibility of procreation. This was especially true for priests, because they took a vow of celibacy. Notably, in Japan's other religion, Shintoism, male-male sexuality is not condemned at all. It is not even mentioned. ${ }^{40}$ In fact, in Shintoism sexuality in general is freely accepted as a natural way of life and many creation stories involve the birth of life through the union of two kami, or gods. Essentially Japanese Shinto monks had a "free pass" in indulging in the occasional company of young boys. They were isolated from women and looked down upon women, but could freely love "beautiful boys" (bidou) because they were not the same and would not result in such "terrible consequences" as children or permanent worldly attachment. They also considered their vows of celibacy to be intact even after being with a chigo, because male sexual contact did not qualify as actual intercourse.

All of this, once again, circles back to the emergence of male-centered entertainment for men. It was priest-acolyte in the medieval stage, followed by the more attainable taikomochi (whether sexual entertainment or simple companionship and amusement), and then into the Edo period with the rise of the red-light districts and the expansion of Japan's sexual world. While the Edo ${ }^{41}$ period is considered the "Rise of Geisha", it also became the "heyday of sanctioned red-light districts" with the appearance of entertainment services and a network of inns that functioned as brothels. ${ }^{42}$ Female prostitutes were certainly becoming more and more mainstream. As acceptable as prostitution got at the time, male-based services were still prevalent and became popular in many ways. Shinjuku's Nichoume was one of Tokyo's unofficial red-light districts all the way until 1956, when prostitution was outlawed. It began as a district for

40 Pflugfelder, 99-101.

41 Also referred to as the "Tokugawa era". The two will henceforth be used interchangeably in this paper.

42 Boyé Lafayette De Mente, Sex and the Japanese: The Sensual Side of Japan (Tuttle Publishing: Tokyo, Japan, 2006), 27. 
women but became home for the "gay brotherhood" when the "fallen sisterhood moved out." ${ }^{43}$ Nichoume remains a gay district in Tokyo today.

Even in decades past, nanshoku was not considered a perversion but a "lofty ideal" as long as the passive role remained only proper for youths and boys. ${ }^{44}$ It became less tolerable if an adult man played the passive role and allowed a boy to penetrate him. So strict were the Japanese about this point that the male passion, nanshoku, became a way of life, shuudou. The term literally means "way of youth" and has been used to describe every aspect of nanshoku, from priest-acolyte bonds to male prostitution, and to works of art and literature devoted to the special relationship between grown men and boys. To travel down the way of shuudou was to fully accept and immerse oneself into every aspect of the lifestyle.

Male priests remained one of the largest groups of consumers of these male prostitutes. Homosexual brothels were very often located near Buddhist temples, offering perfect access for monks. Sometimes, young men who wished to make money through their bodies would even disguise themselves as "incense sellers" in feminine clothes in order to lure potential clients. ${ }^{45}$ These "outsider" boys who dwelled in brothels around the city fascinated the sheltered men of the monasteries. The famous Edo author Saikaku $^{46}$ once wrote of priests entering the entertainment district of Shijougawara for the first time. He observed that the priests "fell in love with handsome youths there, the likes of which they had never seen in the countryside," and as a result began to ignore

43 Bornoff, 427.

44 Ibid., 426.

45 Ibid., 426.

46 Iharu Saikaku (c. 1642-1693) was a poet and is credited as the creator of ukiyo zoushi, or the "floating world" genre of literary prose in Japan. Urban life, and most especially the erotic aspects, was called the "floating world" because of its fantastical way of disconnecting one from the real world. Stories and art depicting these erotic situations were thus also referred to as part of the floating world. 
their religious duties in favor of buying them all up. It could very well be satirical or fictional, but reliable or not, having such an account from the famed author speaks volumes of the clergy's involvement in Nanshoku..$^{47}$

Male companions had influence that was prevalent even outside of brothels. Other types included sandal bearers, lower retainers of well-to-do families (called rokushaku and komono ), incense sellers as mentioned, and other peddlers of goods such as sundry items and fan paper. In addition to their official duties, they were often "rented out" as prostitutes on the side by their regular customers. Most often these boys came from merchant classes and were put to that type of work by another family member or someone of a higher rank such as a master or boss. Some men were even used as objects of "medical healing." For example, engaging in sex with a male prostitute was seen as a treatment for beriberi due to the fact that prostitutes were thought to have jouketsu, or "superior asses", and not dokketsu, or "poisonous asses", because they had mastered the tricks of the trade. A jouketsu was recorded as smelling of "cooked prawns and chrysanthemums" which could soothe the symptoms of beriberi. ${ }^{48}$

Manuals about homosexual intimacy were written, and shops were opened for the sake of properly handling the shuudou life. Yotsumeya sex shops opened in wards that featured male prostitution. They sold many items such as artificial rawhide anuses, lubricants, salves, and other goods deemed necessary for preparation or practice. As hemorrhoids ( $j i$ in Japanese) were a professional hazard ${ }^{49}$ it was very important to have the right supplies. One lubricant in particular gained fame. It was made from the powdered root of a hibiscus plant called nerigi or tsuuwasan. Other ingredients from the 47 Ihara, "Nanshoku Ookagami" 39:467-468 (Great Mirror, 190 [whence the quotation]).

48 Pflugfelder, 237.

49 This was considered the worst of a male prostitute's "professional hazards", whereas it is interesting to note that a female's was hysteria (or shaku). 
most common version of the recipe included seaweed and egg whites. The entire mixture was sold in dry form and could be reconstituted with saliva before use. ${ }^{50}$ Although it could be homemade, it was often marketed and sold with witty tag lines such as "Tenjin no uramen de tsuuwasan" [Tenjin's backgate tsuuwasan]. Clove oil used as lubricant was cited in the fourteenth century CE on a picture scroll, but tsuuwasan was by far the most popular. Those on the receiving end in nanshoku relationships were also advised to eat konnyaku, described as a "firm gelatin paste of devil's tongue," to clear the anus. ${ }^{51}$ Furthermore, the prostitutes could purchase stick medicines, literally a stick coated with copper sulfate that was inserted into the anus in order to dilate it for use. Drug merchants sold all of these preparatory goods by using attractive sales boys who could also find "an appreciative clientele for themselves" and for the druggist's wares. $^{52}$

After the medieval period and into Tokugawa, the client base of nanshoku began to expand beyond the typical clergy customer. The most famous of these new categories of buyers were the samurai and upper elite of Edo Japan. Very much like the Buddhist separation of men and women, the rise of feudalism is also deemed to have encouraged homosexual desire and behavior in males. One major development involved the roles of women. Before the arrival of the samurai in the fifteenth century CE, and the combined influences of Buddhist and Confucian teachings, women had an actual presence within Japanese society. For example, in the twelfth century CE they could own property through inheritance or family lands, and they could keep that property separately from their husband's even after marriage. While inheritance was most commonly patrilineal,

\footnotetext{
$50 \quad$ Pflugfelder, 239.

51 Leupp, 112-113.

52 Pflugfelder, 239.
} 
many women had the right to legally adopt daughters and sons to whom they could leave their properties. ${ }^{53}$ Until the fourteenth century CE, women with properties also had the same feudal obligations as men, which included military and peacekeeping responsibilities.

Although the military was always a masculine space, there are records of women who held important roles or who contributed to battles. Women of nobility were able to hold important military positions.$^{54}$ Some noblewomen are remembered for their battle feats, including the wives of Nikaido Moriyoshi, Narita Ujinaga, and Okumura Eifuku, lords in the sengoku period. These women refused to surrender their castles while their husbands were away, fighting off their opponents or otherwise negotiating with them. A woman called Hangaku was praised for her extraordinary skills with a bow and arrow in one tale, and another named Tomoe was featured in the Tale of Heike which was based on a real battle in Heike. ${ }^{55}$ These accounts suggest that women participated in battle as well. However, women's rights had already begun to get sanctioned in the thirteenth century CE after the samurai failed to fight the Mongol Invasion. A century later, women had been "reduced to a dependent status" with very few rights and usually only a sustenance income from the household head. ${ }^{56}$ By the seventeenth century CE, peasant women completely lost their property rights, and only noblewomen in the shogun's household remained on a payroll. This was not for any leadership position at all, but was determined by the importance of the woman's sexual life with the shogun and whether or

53 Helen Tierney, “Women's Studies Encyclopedia, Volume 2”. (Greenwood Publishing Group, January 1999): 780 .

54 Bonnie G. Smith, "The Oxford Encyclopedia of Women in World History: 4 Volume Set”. (Oxford University Press USA, 2008): 234.

55 Willam M. Tsutsui, “A Companion to Japanese History”. (John Wiley \& Sons, April 2008), 358.

56 Tierney, 780. 
not she produced him an heir. ${ }^{57}$ Obviously the integration of the patriarchal philosophies of the samurai, along with the heavy bias against women in Buddhist and Confucian ideologies, into Japanese culture in the fifteenth century CE, had placed women in a much more submissive role, giving her worth only through the men in her household.

Women were removed from administrative positions in the military they had been able to hold since the fourteenth century CE, and men completely took over these domains. These "strong men" who subjected peasant populations through "their own physical and mental attributes" were considered "sexually attractive" to men and women alike. ${ }^{58}$ Of course their vast amount of political power was also very enticing. These elites, however, were men like any other and had needs that could only be solved by the company of another human being. Spending most of their time with other men, their options were often limited.

Engelbert Kaempfer, a German historian who visited Japan in 1727, wrote that he had seen boy prostitution all over his travels in Japan and that "the Japanese [were] very much addicted to [the] vice." ${ }^{59}$ This, however, was not exactly true. Not every Japanese person accepted nanshoku or shuudou. For the most part, it was considered a regional peculiarity. For example, it was often related to the region of Satsuma, so people of other regions would call male-male relationships "Satsujin tsuuyuu no seiheki" or a "common quirk of Satsumaites" ${ }^{60}$ Furthermore, in many areas, the indulgence of male brothels was considered uncivilized and something only practiced in backward regions. Each area had different laws for buying male companionship, and it depended mostly on

\footnotetext{
57 Tsutsui, 361.

58 Leupp, 48.

59 Engelbert Kaempfer, "The History of Japan Together with a Description of the Kingdom of Siam". 1690-92 trans. J.G. Scheuchzer, 3 (Glasgow: James MacLehose and Sons, 1906): 53.

60 Pflugfelder, 210.
} 
geographic locale and the chronological era that nanshoku had appeared in the region. In general, the "way of men" and the "way of women", or prostitution, was on par with dangers such as excessive caffeine or alcohol consumption. ${ }^{61}$ Likewise, relationships with other males was considered just as addictive. Gregory Leupp writes "Nanshoku was an inclination common to all men, but some were more vulnerable to it than others. ${ }^{.62}$ Just as some men could become alcoholics, others could become too involved with their paid companions.

One of the reasons samurai and important members of the upper society participated in shuudou was that the demographics of castle-towns in the Tokugawa period were vastly uneven in favor of males. In 1733, urban commoners alone (excluding samurai, clergy, and outcasts) made up a population of 340,277 males to only 196,103 females. ${ }^{63}$ Another reason was naturally the influence of clergymen. Buddhism was the religion of choice for elites who had long embraced its teachings. Because the male-male culture was so firmly established it was not surprising that it spread to the rest of society. Samurai modeled their relationships after the monk and courtier traditions of the past. They respected Buddhist monks and because of that, and the "institutionalized devaluation" of women as indoctrinated into Buddhist practices, readily accepted and adopted homosexual practices. ${ }^{64}$ Conveniently, samurai very often received their educations in monasteries.

Drawing from the bond between lord and vassals of castle-towns in addition to clergy customs, the samurai developed their own system of male companionship. An

\footnotetext{
61 Leupp, 147.

62 Ibid., 146.

63 Nishiyama et al., "Edo gaku jiten”, p. 638; Takeo Yazaki, "Social Change and the City in Japan: From the Earliest Times through the Industrial Revolution" (Tokyo: Japan Publications, 1938).

64 Leupp, 51.
} 
older samurai always mentored younger soldiers. As mentioned at the beginning of this chapter, this setup created something resembling the teacher-student bond between the men of Ancient Greece. The elder soldier was originally referred to as nenja and the younger was called nyake, which was written with the characters for "youth" and "spirit", but was eventually used as slang for "anus". ${ }^{65}$ Many fans of samurai today are far more familiar with the later titles. By the $17^{\text {th }}$ century, it was more common to refer to the senior as anibun (big brother) and the junior as otoutobun (little brother).

In order to grasp shuudou as it was practiced within the samurai class, it should be understood how different the bond between the samurai and their retainers was. It was not thought of as incestuous for two "brothers" to engage in intimate acts together. To the samurai, the bond they shared with their juniors was something that could not possibly be described as only "love," "lust," or "brotherhood." It was far beyond that, a bond deeper than any other in the world. A treatise written for samurai in the early Tokugawa era states:

"[t]o throw away one's life [for one's male lover] is the ultimate goal of shuudou. Otherwise it becomes something shameful. But then one has no life to give in service to one's lord - so it is both agreeable and disagreeable." 66

As a samurai's life was based upon honor, these men were constantly advised in all areas to act in moderation. However, the lifestyle also decreed that a samurai should never do anything halfheartedly. It was a bit contradictory perhaps, in terms of nanshoku, but the baseline was that keeping the company of other males was a very important and

\footnotetext{
65 Ibid., 43.

66 Ibid., 48.
} 
paramount part of life.

The ideal partner for any type of companionship during the Tokugawa years was a boy between the ages of fifteen and eighteen. As life expectancy during that time was only about fifty years, it was important for boys to assume adulthood at very early ages. ${ }^{67}$ The "peak" of youth was thought to be between those ages, and what made them so enticing for an adult male was that the beauty of young males was not only distinguishing but fleeting. Beautiful boys were directly comparable to short-lived blossoms such as cherry or plum. Any age after eighteen was revered as a time of evolution from that cherry blossom to "manly honor," a new level of maturity that truly "refined" the pleasure of experiencing shuudou. ${ }^{68}$ Watching a partner develop into a man was very rewarding and proved that the mentorship was a successful and appropriate one.

Typically the end of the wakashu stage was anywhere from twenty to thirty years old, though sometimes it was even beyond that. There was "considerable plasticity because manhood was essentially a social condition, its biological referent far less important than its cultural markings." ${ }^{69}$ If a young man never participated in the custom ritual of manhood, he would never officially be considered a full grown man. This was far more important to the Japanese of the early modern era than actual age was. This coming of age ceremony was called Genbuku. At this time, and there was never a fixed date, the forelocks of the youth's hair were shaved off and his furisode $e^{70}$ was exchanged for adult male clothing. Once this was complete, the male was supposed to no longer

67 Ibid., 122-23.

68 Pflugfelder, 31.

69 Paul Gordon Schalow, Male Love in Early Modern Japan: A literary depiction of the Youth (1989).

70 A furisode is the most formal type of kimono for an unmarried woman, distinguishable by its long sleeves (furisode is literally translated as "swinging sleeves"), that range from $85-114 \mathrm{~cm}$ long. 
invite the "erotic intentions" of another man. This ritual occasionally did not happen, but such an occurrence was rare. One daimyo ${ }^{71}$ in 1708 wanted to prolong the coming of age ceremony of his page boy lovers, refusing to let them participate in it until the age of thirty $^{72}$ because they would be considered men and their relationship with the daimyo would no longer be appropriate. Not all young boys had a relationship with older men, but anyone who grew up within samurai households or had a samurai employer would want to at least establish a bond with one or more superiors.

Unlike simply indulging in a few hours of paid company, a samurai and his boy would have a very serious relationship which was not invariably sexual in nature. Often the participants of a nanshoku agreement would go to great lengths to display their loyalty to one another, even going so far as to sever fingers or other such extremes. Some nanshoku pairs would even create a written contract entailing the various vows that would nullify the relationship if broken. It is rare to find texts like these, but this is an example from a Tokyo University Historical Archive's text written by twenty-twoyear-old Takeda Shingen, one of the most famous warlords of feudal Japan, in 1543:

Item: Although I have sometimes said to Yashichirou, "Let's have sex," he has refused me, saying, "I'm having stomach problems and am not feeling well." Item: Yashichirou has never slept with me as my attendant in bed. To date, that has never happened. Not only have I never had sex with him at night, but never in the daytime either. Especially now, I have no thought of having sex with him.

Item: Since I want to become intimate with you, from now on if you have any doubts about these things, I want you to understand that I do not plan to hurt you. If I should ever break these promises, may I receive the divine punishment of the Great Myoushin of the First, Second, and Third Shrines of the province of Kai, Mount Fuji and Shirayama, and particularly Hachiman Bosatsu, and all the higher and lower deities. ${ }^{73}$

\footnotetext{
71 The daimyo were lords in feudal Japan who served as vassals to the shogun.

Pflugfelder, 33.

73 Leupp 54-55.
} 
Shingen's sixteen-year-old lover was jealous of the Yashichirou in the contract, and requested a written contract before agreeing to the relationship. Some warlords had only one lover at a time; others would engage several at once. That was cause for much jealousy among the younger lovers but in some cases it did not matter, since being the sworn brother of a samurai could vastly improve one's lifestyle and getting jealous over others was not cost effective. Many shogun themselves often had "huge harems". They were affluent men who had access to whatever kind of pleasures they desired. One author even says of these influential men that they had such a "variety and volume of sexual activity" with men it has "probably never been surpassed on a nationwide basis in any other country, before or since. ${ }^{, 74}$ In studies of this time, the great achievements or downfalls of these men have been well documented, but their personal indulgences have not been nearly as well known. Whether or not nanshoku was actually prevalent everywhere in Japan still gets mixed responses. Again, this is likely due to Japan's attempts to disassociate with any sort of homosexual culture.

On the topic of acceptance, people who were not of the military or affluent classes were still exposed frequently to the lifestyle of nanshoku and shuudou. Commoner men did not engage in "brotherhood bonds" but they still visited prostitutes (male and female) in brothels. Many chounin ${ }^{75}$ became entrepreneurs of the pleasure business and established "some of the most extensive and elegant urban pleasure districts" available. ${ }^{76}$ Immigrants moving to castle-towns were exposed to samurai traditions as well. The men and women who made up these lower classes were so used

\footnotetext{
74 De Mente, 27.

75 Merchant or merchant class men.

76 Leupp, 65.
} 
to the homosexuality that it was often considered an official part of being a soldier. The famous saying, "Nanshoku wa bumon no hana [Nanshoku is the flower of the military class]" illustrated this tradition. Those words can be interpreted as both positive and negative. Many lower-class people mocked homosexuality in the military, but others believed it to be completely harmless. Women overall were more accepting of the relationships than men who controlled the status and reputation of their families or clan. One strong belief among the lower classes was that since nanshoku was the "pasttime of the samurai", and samurai were highly respected, there was no way such a custom could be harmful to "good government". 77

The sentiment that accepting everything the samurai did was not always felt or understood by foreigners and visitors in the Tokugawa period. But these foreigners rarely failed to notice the prevalence of male company. Jesuit missionaries considered early soldiers to be "back-stabbers who 'rebel ... when the opportunity presents itselff.",78 The missionaries were not by any means impressed by the military society and did not agree with samurai beliefs. Brotherly bonds meant nothing and the priests did not feel the soldiers were genuine with them. It was also noted that the Japanese had significantly altered one of the main parts of Chinese Confucianism, wherein there was a hierarchy of respect in every man's life. In Japan, loyalty to one's lord overrode all else, including one's parents, wife, and children. To many foreigners, whose nuclear family took precedence, this seemed strange.

In sum, is that subservient males, males available to entertain clients had been present in Japan since very early times, and by the Edo period, it had launched into a

77 Ejima Kiseki. "Nihon meicho zenshuu," 9 (Tokyo: Nihon meicho zenshuu kankoukai, 1926-1929): 619.

78 Leupp, 49. 
booming business that would only continue to grow. The general nature of these boys, the types of customers, and the reason for any of it to exist at all, however, is one thing that has remained constant throughout time. 
CHAPTER THREE: THE FLOATING WORLD OF FICTION AND THE KABUKI

\section{CRAZE}

While male companionship evolved in real life, it also existed in a world of fantasy. Poetry, paintings, picture blocks, and texts (fictional and not) were often used as outlets for individual fantasies about unexpressed or unobtainable sexuality. Fictional works played an important role to the nanshoku lifestyle or for anyone who did not fit his or her expected social role. This remains true in Japanese culture today where social "outcasts" find outlets in printed media. While it may appear to be a completely different topic than men who put themselves into submissive or homosexual roles in Japan, there has always been a link between history and popular culture. Japanese erotica prints with explicit male-male scenarios are well known in the world today, however, the history of male eroticism is a much more elusive topic.

The subjects of these picture scrolls (emaki) varied. They could be personal portraits illustrating specific rituals or customs, or simply plain smut. Many scrolls even portrayed both men and women pleasuring another man. A common theme featured an adult male with a female prostitute and a young boy (usually another prostitute or a page boy), all sexually servicing one another. Other scrolls had no women in them at all. One such scroll from the Kyouhou period (1716-1735) pictured a high-ranking samurai with his son and entourage preparing to go on an outing. Although there were many courtesan fashions of the time, they were all young boys wearing them. The samurai is accompanied by a kabuki actor wearing a purple scarf, indicative of his profession. ${ }^{79}$

When the popularity of emaki increased, literature with homosexuality also

79 Leupp, 52. 
became widely available to men with such interests. The books were easy to obtain with the spread of printing technology, the growth of the publishing trade, and an increasing demand for erotica of all kinds. ${ }^{80}$ Subject matters also varied vastly in the written form, from samurai lovers to very graphic sexual descriptions, and even manuals on how to perform or act in certain ways.

The most commonly represented erotic act was anal coitus. Fellatio and other oral acts with the exception of kissing were rare or otherwise used only as humorous anecdotes. Fellatio and some forms of intercrural sex were considered obsolete or disreputable in Japan. ${ }^{81}$ In literature and actual practice, pleasure was never reciprocated for shuudou pairs. The passive partner seldom enjoyed penetration and an erection could be "annoying" for him. ${ }^{82}$ A partner who enjoyed any act with his shuudou partner was considered vulgar and shameful, especially if he continued to enjoy such attention after entering adulthood. A man should not enjoy being submissive to anyone and if he did, he might not ever grow out of the mode of behavior, which would be shameful.

The first reference to the word "shuudou" can be found in a document dated 1485. It is an abbreviation of wakashuudou which, once again, means "the way of youths. ${ }^{" 83}$ Males in erotica appeared much earlier than that document, however. Crossdressing males showed up in Japanese fiction as early as the twelfth century CE in a story titled "Torikaebaya" or "The Changelings." 84 The "Chigo monogatari" or "Stories of the acolyte(s)" was written in 1377 , followed by seven others during that time.

\footnotetext{
80 Ibid., 80.

81 Pflugfelder, 41-42.

Ibid., n. 50-51.

Watanabe \& Iwata, 48.

Leupp, 26.
} 
Homoeroticism also made an appearance in Noh ${ }^{85}$ plays, “Kagetsu” (Flowers and Moon), "Jinen koji", 86 "Tougan koji”, and "Seigan koji”. They were all written before $1423 .^{87}$

Shuudou texts that taught youths how to be proper and desirable for nenja were available along with fictional novellas and plays. It was important that these "manuals" existed because any faux pas committed by the younger partner would reflect negatively upon his older lover. A priest named Sougi wrote two manuals outlining proper behavior for the chigo who became lovers. ${ }^{88}$ Aside from these how-to books, wakashu were rarely the targeted audience of these works. Their desires were hardly ever addressed. It was considered a "blessing" for fans of shuudou. ${ }^{89}$ This arrangement, that of nenja and wakashu, was ideal for men wishing to pursue pleasure. Relationships with women came with responsibility and priorities far more important than enjoying oneself. Shuudou stories were structured much like real life relationships. The nenja was the lover, who could be young, but he was always senior to his younger companion. This was because a wakashu could become a nenja, but it could never happen in reverse. The nenja role was the partner who was penetrated, and who could in fact be purchased by a man. If he desired a youth enough but had no other means of obtaining him, he would purchase his position as the lover. ${ }^{90}$ You may note the similarity of buying a host in Japan today.

The writers of shuudou highly praised the indifference of a youth toward social

85 Noh is a traditional form of Japanese drama, performed wearing special masks. The plays are evolved from Shinto rites.

${ }^{86}$ Jinen koji, Tougan koji, and Seigan koji are all eponymous titles. "Koji" is often translated as "lay monk" or "lay priest".

87 Leupp, 40.

88 Ibid., 42.

89 Pflugfelder, 55.

90 Ibid., 57. 
status, but jealousy and rivalry in the stories were also very popular. Brotherhood was romanticized far more than marriage which was seen as superficial compared to the deep bond between men. Shuudou very often included formal contracts of devotion, discussed previously in the chapter. They would write of oral or written vows that were very dramatic "loyalty tokens." Some examples were self-mutilation, piercing flesh (the thigh or arm), removing fingernails, or cutting off a finger, one of the favorites of Japanese fiction. ${ }^{91}$ That ritual eventually carried over to the yakuza, who performed it to show loyalty and apology after shaming their leader.

The Japanese always praised stoicism, so readers could freely indulge in the dramatic or overly romantic in works of fiction. Even the very famous novel The Tale of Genji, written by the female author Lady Murasaki, featured some shuudou when the eponymous character Genji slept with the little brother of his female lover. Mokozu monogatari, or "Seaweed stories" written in 1640, was the prototype for love-suicide tales which became extremely popular. This "foreshadowing" extended to real life lovesuicide situations, especially with heterosexual couples. Another example of the genre's growth was the Shuudou monogatari, a 1657 book of illustrations. It has been cited as "perhaps the first illustrated book aimed at a mass market in Edo."

Male-male erotic texts would eventually boom in the Edo period, sharing the spotlight with the rise of brothels and sexual businesses. The books were truly at their most popular in the eighteenth century, ${ }^{93}$ no doubt a development that correlated with the change in accessibility. They were no longer confined to tight, very specific circles of readers but available on the open market for anyone to purchase. Despite this, male-

\footnotetext{
91 Ibid., 40-41.

Takashi Kobayashi, Ukiyoe (Kodansha International: Tokyo, 1982): 35.

93 Pflugfelder, 45.
} 
male erotica did eventually draw in a certain kind of audience. Now that the books were obtainable to them, shuudou became very popular for the "townsmen" social group. Artisans and merchants had access to the materials and became not only the biggest consumers but the largest group of authors too. ${ }^{94}$ It was now perfectly feasible for the lower and middle classes to imagine themselves in a samurai romance or as members of a much finer society than the one they lived in.

Shuudou texts were so trendy that they needed to be regulated to keep the fictionalized stories from embarrassing the country. The Shogun passed many restrictions to preserve the integrity of Japanese males. In 1657, an Edo decree forbade the sending of "outrageous" (read: explicit) letters to the children of townsmen and pages renewed ${ }^{95}$ on account of the nanshoku lifestyle encouraging inappropriate behaviors. In later years, state censorship laws went into place. The strict new rules for taming the "floating world" affected every part of the male-male lifestyle. Books were not the only media that was heavily restricted, kabuki plays and erotic pictures were regulated as well. One kabuki play written in 1712 was banned in 1899 for threatening public morality. The "pictorial representations" were banned completely and merited harsh punishment if ever found. ${ }^{96}$

What had begun as a simple escape from the "real world" became an extremely profitable but dangerous enterprise. While many fantasy romances escaped the government radar for much of their existence, gaining too much popularity spelled its downfall. However, although erotic texts and pictures experienced a brief decline in consumption, they never disappeared. From medieval Japan to Edo and into the

\footnotetext{
94 Ibid., 76.

95 Ibid., 112.

96 Ibid., 201.
} 
contemporary world, erotic or simply romantic works of fiction became a staple in the nation's economy. It was only the audience and the purpose of those works that had changed. The next chapter will deal with how acolytes and samurai boys led to kabuki and prostitution, and how those professions are linked to host clubs and Pink Japan today.

While some members of the samurai, clergy, and elite classes were engaged in official relationships with wakashu, men also hired dancers or other entertainers for jobs that went beyond their official duties. As stated in previous chapters, some taikomochi performed as entertainers for all-male gatherings. During the same time period there were many diary entries detailing various meetings between young male entertainers and their patrons. Yorinaga Fujiwara wrote in his journal in 1142 that he summoned a dancer to his home at midnight. Later in 1147, he wrote about two instances of going to bed with entertainers. The following year he wrote "Tonight I took Yoshimasa to bed and really went wild; it was especially satisfying. ${ }^{\circ 97}$ Organized, large-scale male prostitution dated from the late sixteenth century, but many young men had been supplementing their income through sexual companionship for centuries before that. Kabuki, Noh, and even street actors always entertained men, and continued to do so throughout Japan's history.

The origin of the kabuki craze can be traced back to the seventeenth century CE, triggered by the fact that women's kabuki was banned in $1629,{ }^{98}$ because watching females on a stage became far too lewd to be acceptable in a respectable society. Females were no longer allowed to act on stage, and were replaced by wakashu actors

\footnotetext{
97 Leupp, 25.

98 Pflugfelder, 114.
} 
instead. This change initiated the usage of onnagata and otokogata roles within the kabuki theater, that is, men played all male and female roles. Due to perceived negative influence on public morality, female actors were banned from the theater so that they could no longer distract the patrons. An all-male cast, on the other hand, would enable the patrons to fully concentrate on the plays. As many of the patrons were samurai, however, the attempt thoroughly failed. Due to the samurai embarrassing their class, wakashu kabuki also became forbidden. Occasionally two samurai argued over one kabuki actor, even going so far as to turn to violence. Regardless, wakashu kabuki returned only one year later. ${ }^{99}$

The onnagata actors became more popular than even their female predecessors, as they appealed to both genders for varying reasons. Because they lived as women and served as a female "impersonation," they appealed to men. At the same time, they were the celebrities of seventeenth century Japan, and females "eagerly took note of" onnagata fashions. ${ }^{100}$ Young men in female roles did not fit into the typical masculine mold and were generally a positive thing for women. Women were discouraged from expressing their feelings directly due to their perceived gender inferiority. But male actors who played female roles escaped from reality and could express things that "women might not commonly feel but that men (and women) in the kabuki audience might want to hear."101 In that way, the onnagata played into male erotic fantasy, but they were also a mouthpiece for women. It did not offer much respect or freedom for women, but it was one of the only outlets they had for expression. The cross-dressing actors were admired by all, not just on stage but also in private quarters. The actors

\footnotetext{
$99 \quad$ Ibid., 114.

100 Bornoff, 427.

101 Leupp, 177.
} 
would be patronized as prostitutes by men and women, even when it was illegal for men to visit a woman's house (if he was not related or married to her). ${ }^{102}$ Female patrons of onnagata were just as popular as their male counterparts, and the most frequent customers were widows of affluent men or generally women from upper class families. It was so popular for women to become infatuated with female role actors that humorous, lyrical poems were even written about it:

\section{"okama no \\ baku-baku wo \\ goke wa kai ni kuru.}

The widow

hurries off

to buy a female role actor." 103

The popularity of kabuki stage actors can be somewhat misleading in light of how they were treated by the Japanese society as a whole. They had many fans and patrons, but actors of any kind ranked very low on the social ladder, above only outcasts.

Nevertheless, an actor could earn a grand salary despite his low rank. Ayame Yoshizawa became the first actor to earn over 1,000 ryou $^{104}$ per year as an onnagata. ${ }^{105}$ The incentive for an actor to sell himself was high, not just for the income but also the flexibility to be exclusively purchased by more than one man or woman. A very popular actor could receive gifts and money from more than one avid fan, making it a lucrative

\footnotetext{
102 Ibid., 175.

103 Katsutada Suzuki, Senryuu Zappai kora mita Edo shomin fuuzoku (Yuuzankuku: Tokyo, 1978).

104 The ryou is an outdated currency that was used in pre-Meiji Japan. It would later be replaced by the yen. Since the conversion rate fluctuated and is difficult to accomplish now that the currency is out of use, 1000 ryou per year could have been anywhere from approximately $\$ 30,000-\$ 1,000,000$ today.

105 Leupp, 130.
} 
profession indeed.

Because the theater was thought to be a dangerous pastime like gambling or drinking, drawing too much attention to any part of it was considered an embarrassment. Samurai and other patrons alike could get wild over their favorite actors even to the point of dueling or large brawls in front of the theaters. One "clampdown" on kabuki was actually triggered by the affair between a woman from the Ejima (samurai) family and an actor named Ikushima. ${ }^{106}$ While on an excursion for the shogun's mother, Ejima had an affair with Ikushima, which carried on for at least seven years. She even adopted one of his children into the household she served, claiming the child was the daughter of a samurai family. ${ }^{107}$ Both Ejima and Ikushima were exiled briefly. Such scandals became very common.

Eventually, the government intervened for sake of face as the scandals became embarrassing, reflecting negatively upon the image of Japan. Many attempts at regulating the "urban shuudou culture" in kabuki theater were made. The theater was strictly confined to specific districts, and actors could not wander freely. Onnagata could no longer wear their forelocks long like a woman. Theater companies fixed this problem by allowing the actors to wear wigs, and the onnagata did not lose any pull on the theater-going population. The government also severed the link between the theater and prostitution and banned kabuki of blatant eroticism on stage. Predictably, these measures did very little good. ${ }^{108}$ If anything, the restraints only served to make the interest in onnagata stronger and the line between prostitution and performing very thin. Despite all the attempts to stop such behavior in the theater community, male and female

\footnotetext{
106 Bornoff, 167,

107 Zoë Kincaid. Kabuki, the Popular Stage of Japan. MacMillian Press, 1925.

108 Pflugfelder, 112-113.
} 
prostitution continued well into the nineteenth century until it took the more vague form that it has today. In the Yoshiwara district of Edo, actors were bought as erotic companions, brothels in the guise of tea-houses rose up, and even the proud taikomochi, who were sometimes quite vehement about not using their bodies for pleasure, began to integrate "bawdy dances or strip-teases" within courtesan brothels. ${ }^{109}$ The prostitution enterprise was expanding rapidly due to many reasons.

First, by the late seventeenth century, the merchant class was getting wealthier, a development threatening to the social system of Edo. Because some commoners were getting more money, they could spend it on things at their will, including patronizing prostitutes and geisha. With the sudden draw of the theater came the courtesans' and actors' influence on things such as fashion and even on intangibles such as language and mannerisms. ${ }^{110}$ The growing influence of the new middle class had a lot to do with the entertainment industry. Prostitution gained attractiveness and the middle class provided both the demand and the supply.

Another reason for the rising popularity of the erotic entertainment industry was the poverty of those who remained in the lower class. When pawning off daughters was no longer enough, a desperate family would also offer their sons either to be trained as an actor, or simply "sold" to teahouse proprietors. Selling or purchasing human beings was outlawed. However, these "proprietors" slipped through the loophole by indentured servitude for boys aged 8 and up, for up to 10 years. The boys did not receive any of the advanced payments, and they were usually trained and employed as prostitutes from quite a young age. ${ }^{111}$

\footnotetext{
109 Leupp, 133.

110 Ibid., 168.

111 Ibid., 134.
} 
Eventually, teahouses and playhouses profitably coexisted. Males and females alike could bring their favorite actors to a teahouse and purchase some quality time alone with them. Teahouses also employed the newly implemented kadomoya, or "boy houses," to supply the shop with youthful prostitutes. ${ }^{112}$ This too was illegal, but nonetheless existed since they all fronted as actual establishments that served tea and light snacks to its customers. By the end of the seventeenth century, male brothels had sprouted up not only in large cities but "also in large villages, post stations, and small temple-towns." 113 Male entertainment began in the three major regions of Japan: Edo (modern day Tokyo), Kyoto, and Osaka, but expanded to Nagoya, Sendai, Hiroshima, Sunpu (now Fuchuu), and Wakamatsu. Sex was reportedly available in "over a dozen towns and post-stations in 18 provinces from Mutsu to Aki." ${ }^{114}$ Yoshiwara, the famous kabuki district, became a very successful red-light district with popular prostitutes likened to cherry blossoms. ${ }^{115}$ If an actor or a tea house employee was popular enough, he and the proprietor could make a hefty profit. Sometimes a buyer wanted to show off his taste and class by spending an exorbitant amount of money on one specific boy.

Other times he simply wished to win the boy over other buyers. ${ }^{116}$ This is directly similar to host clubs today, where clients may sometimes steal the attention of their host away from a different customer by buying a more expensive drink.

The kadoyama business was straightforward in its way of operation. Typical patrons came in all varieties, from Buddhist priests and samurai, to peasants, packhorse drivers, river forders, woodcutters, and fishermen. Women were able to rent boys as

\footnotetext{
112 Pflugfelder, 120.

113 Leupp,63.

114 Ibid., 67.

115 Bornoff, 188.

116 Pflugfelder, 78.
} 
well. In fact, females could easily acquire pornography, sex toys, and any services of male and female prostitutes alike during the Edo period, even though there was a fair amount of social stigma associated with the activities. ${ }^{117}$ During the "height" of teahouse prosperity, "perhaps the most typical patron was the foppish young bourgeois rake, dissipating his allowance (or his inheritance) on ${ }^{118 "}$ all kinds of prostitutes. It was supposedly a standard routine, in fact, to visit a nanshoku house once per every five or so visits, so the "wealthy rakes" did cover much ground in the theater districts.

These patrons would enter a house (assuming they were not bringing an actor, of course) and choose whichever boy they wanted. Many teahouses created rosters of their employees and gave a tiny bit of information based on various customer tastes. One such example is this roster from a house in the Doutounbori district of Osaka:

Hanayama Tounosuke - 14 - fair complexion, lovely eyes, recites kodaya tunes. Iwataki Isaburou - 16- skillful dancer, sings nage tunes, naturally imitates the manners of a woman.

Yumekawa Dairoku - 15 - good drinker, who can keep up with anyone. Plays shamisen well, and is the most attractive of those dressed like traveling performers.

Matsunokaze Kotonojou - 17 - good at making shadow figures, and can spit water from his mouth to write characters on the wall. In juggling, he rivals Shio no Choujirou.

Fukakusa Kankyuurou - 17 - in his manner of speaking, he closely resembles the late Suzuki Heihachi [wakashu role actor]. He has no special skills but is wonderful in bed!

Yukiyama Matsunosuke - $19\left(\mathrm{yarou}^{119}\right)$ - when he sits in the room, it is easy to mistake him for a real stage actor. ${ }^{120}$

117 Leupp, 191.

118 Ibid., 77.

119 A yarou was considered a little older than standard, and was often a little more masculine as well. They were often the counterparts to onnagata on stage. There was also a type of kabuki that centered on the yarou character.

120 Leupp, 133. 
Once the selection was made, the customer and his chosen boy went to a room together. Fees depended on the rank of the boy, similar to the hierarchy of courtesans in brothels. Highly ranked boys were able to get even higher fees than female prostitutes. In Kyoto, a male prostitute could get paid "129 monme $e^{121}$ for one night of sex," and the highest paid courtesan could get was only 58 monme. A "common teahouse prostitute" made about 5 monme. ${ }^{122}$ Young male prostitutes would attempt to prolong their youth for as long as possible. Eventually their clientele would shift to female patrons once the male aged. One short humorous lyric from the $18^{\text {th }}$ century satirized boys who "reached the age where his prick [sold] better than his ass. ${ }^{" 123}$ Business carried on as usual, with barely a shrug from the government's shoulder. Despite male prostitution being highly institutionalized within theater districts, it was not acknowledged or taxed as female prostitution was. All prostitution was accepted as long as all business transactions remained in their designated districts, ${ }^{124}$ though male prostitution was omitted from official decrees to continue to save face for the government from prostitutes. Officials could not recognize males that sold themselves in any capacity.

With the rise of kabuki in the 1600s and the boom of business in the 1700s, the mid-1800s saw the decline of the tea houses in favor of female brothels. This was the time when women began to dominate the entertainment industry. In the Tenpou era (1830-1843), there were only two tea houses with ten boys remaining in the town of

121 Monme were part of the same currency system as the ryou. They were a lesser valued silver coin, where about 40 monme equaled 1 ryou.

122 Ibid., 71.

123 "Ketsu yori ka henoko no ureru toshi to nari.", Yakou Yanagidara, "Yanaibako." Shodui Senryuu Senkushuu, quoted in Pflugfelder, 34.

124 Pflugfelder, 120. 
Yoshichou. Reportedly, male prostitution was down by $90 \%$ since the Edo period. ${ }^{125} \mathrm{~A}$ total of four boy houses were still in operation by the 1860 s, whereas female entertainment became a much more lucrative business. The Meiji Restoration also heavily damaged the male entertainment business as it scattered priest populations, severely limiting the pool of clientele. ${ }^{126}$

In the region of Kagoshima, once considered the "epicenter" of male-male activity, visitors could tell that female brothels were running tea house out of the spotlight. It did not help the male entertainment business that female prostitution was legal in Kagoshima in $1888 .{ }^{127}$ Male prostitution, once again, was swept under the radar as long as it contained itself.

That is not to say that there was no government crackdown on male prostitution. In the Kyouhou (1716-1735), Kansei (1787-1793), and Tenpou (1841-1843) Reforms, all "lewd" art, literature, commercial sex, and general extravagance were attacked. In 1842 toward the end of the Tenpou Reforms, all of Edo's teahouses were ordered closed. 128

The Tenpou Reforms aimed to "restore Japan to her rightful glory and security," 129 although it is largely considered by historians to have been a failure due to peasant revolts and the eventual overthrow of the Shogunate approximately thirty years later. The peasant class suffered from severe poverty, and the government had very large debts to settle thanks to several natural disasters and famines that had occurred.

\footnotetext{
125 Nishiyama, et al, “Edo gaku jiten”, p. 557.

126 Plugfelder, 156-57.

127 Pflugfelder, 208.

128 Leupp, 78.

129 Suzanne Holcomb, “Edo Bakufu: Samurai Shogun's Council” (paper presented at the Second Schools'
} United Nations Symposium, Quebec, Montreal, 2015), http://www.ssuns.org/guides/edo.pdf. 
Tadakuni Mizuno, the chief minister the Edo Shogunate, issued the reforms in 1841 and invoked a Kienrei, the cancellation of several large debts. He also tried to collect large amounts of government funds from merchants. ${ }^{130}$ Additionally, the government felt that the merchant class was getting out of control by promoting luxuries and commercial goods outside of agriculture and other necessities. The reforms attempted to shut down the "unbecoming" businesses in order to regain the social morality. ${ }^{131}$ All in all, because the economy of Tokugawa Japan was very Confucian, the Tenpou reforms were an attempt to regain balance. The samurai were needed for order, the peasants cultivated fields to nourish the people, the artisans crafted utensils that people used, and the merchants exchanged "what one has for what has not" and helped the people. If one thing outweighed another, i.e. the merchant class tea-houses, the entire country would fail to prosper. This was a summation of early reformer and Confucianist Ogyuu Sorai on the economic thought of Tokugawa. ${ }^{132}$

Even though the reforms were not extremely successful, male services took huge blows after the Edo period. Male prostitution retreated into the shadows, but did get publicity from bouts of murder and aggression. These men were viewed with both curiosity and condescension, because their lifestyle was so different than the norm. The one certainty was that the world of prostitution was always "wareware to wa bessekai," or a completely "different world." ${ }^{133}$ By the official Meiji period, male prostitution had slipped out of the public eye and into many other forms.

Although the onnagata and kabuki in general remain to this day a significant part

\footnotetext{
130 Toshio Suzuki, “Soul Federation”. (Xlibris Corporation, 2010): 229.

131 David L. Howell, "Hard Times in Kanto: Economic Change and Village Life in Late Tokugawa Japan” Modern Asian Studies, Vol. 23 No. 2 (Cambridge Press, 1989): 357.

132 Albert M. Craig, "Chōshū in the Meiji Restoration”. (Lexington Books, 2000): 63.

133 Pflugfelder, 331.
} 
of Japanese culture, the patronage of actors shifted to that of geisha. Male entertainers took on many forms and their services underwent many transformations. A young male may have been employed as a "masseur" in foreign settlements or as a "Tokyo milk boy." The kagemajaya became reborn in the form of a ryokan, a special inn for male prostitutes. In Asakusa (a region of Tokyo), there were two ryokan with at least 50 men combined under their employment. ${ }^{134}$ Some men also became a sanuske, the male counterpart to the female $y u n a^{135}$ or bathhouse attendant. Males could be employed to scrub the bathers' backs and were usually available for special services. ${ }^{136}$

Physical shifts in the male-male entertainment were not the only changes. The very concept and routine of the kagema lifestyle evolved into a more advanced business. Even the terminology changed, as douseai (same-sex love) and iseai (cross-sex love) replaced the words nanshoku and joshoku (the love of girls). These were sexual alternatives that only applied to what was available to men originally. The wakashu and male lovers of the Edo period were objects of erotic desire, but in the twentieth century CE they had transformed. Kabuki actors were no longer the staple males of the industry, though they did remain "actors" in a sense. The kagema began to adopt personas that catered to specific desires. They developed "distinct sexual personalities", from the passive lover to the very perverted type. ${ }^{137}$ Not only could one now purchase the company of a man for a few hours (or a night), there were significantly more options available for customers. A woman who wanted a prince could go to one type of place, whereas a man who favored the feminine onnagata character could go to another. This

\footnotetext{
134 Ibid., 319.

135 Lit. "hot water woman".

136 Leupp, 64.

137 Pflugfelder, 321.
} 
sort of arrangement that bloomed in the Meiji period is the knot that ties onnagata, wakashu, and taikomochi, to the modern day host man. 


\section{CHAPTER FOUR: PINK JAPAN}

“Ottou wa sotomawari, tsuma wa uchimawari."

The husband outside, wife inside. ${ }^{138}$

By the time geisha appeared in the $18^{\text {th }}$ century, the need for men to entertain other men dwindled, though never fully disappeared. Taikomochi were performers of the past, and the kabuki theater eventually separated from the red light district after its glory days in Edo. By the early $20^{\text {th }}$ century, male prostitution circled back to a relationship with the stage. Referred to as the "new kagema," for their clients. Since shuudou and nanshoku had faded, it was unusual for men to seek out other men. Geisha not only pushed the industry toward women, but also began to take over the history of their male predecessors.

By the 1930s, male entertainers once again had their own "domain" within large Japanese towns, essentially the same locations as they had been with the "old kagema". Asakusa in the Tokyo area was one of the top places during the 1930s where males could have encounters with other males. Because the activities occurred in those specific areas, it was very easy for clients and workers alike to maintain however much anonymity they wanted. Men were able to enter public spaces in a place like Asakusa, find a stranger "to strike up a conversation" in "parks, sidewalks, [or] restrooms," and complete their transactions all while keeping their public identities and reputations secret. ${ }^{140}$ There were no repercussions for the behavior and, since everyone else in the district was looking for the same thing, there was no judgment either, only self-

138 Anne Allison, Nightwork: Sexuality, Pleasure, and Corporate Masculinity in a Tokyo Hostess Club (University of Chicago Press: Chicago, 1994): 91.

139 Pflugfelder, 318.

140 Ibid., 318. 
consciousness in seeking these affairs due to outside stigma.

World War II changed the "floating world" yet again. Many reputable geisha houses closed down or downsized significantly, and foreign soldiers occupying Japan were lured by knock-offs of the famous performers. Because Americans and Europeans either did not understand the culture behind the geisha, girls or Madams earned easy money by simply advertising themselves as geisha or maiko ${ }^{141}$ and offering sexual services. Men too found an easy way to earn money during the Occupation. Male prostitutes would wear female clothing and pull their potential clients in because they were mistaken for unlicensed female prostitutes. These men were eventually referred to as panpan, after "pom pom girls", titled after girls who wore a lot of make-up and waved pompoms in order to attract soldiers.

Within six months of the Occupation after World War II, male prostitution went back into business. An article in 1947 stated that "more than 60 male prostitutes made in a living in Sannouchou, where they had relocated from a burned out Kamagasaki." ${ }^{142}$ Likewise, up north, the men popped up in Ueno Park and other similar areas. Female prostitution was regulated and accepted under certain government restrictions (i.e. they had to be licensed). Hostess clubs had been running since the 1920s, but male prostitution was still more or less shunned by the general public. Once men could buy beautiful women as company, there was no need for male performers, only male prostitutes. This would change in the 1960s when the client pool for male workers shifted back to involving females. This time it was almost exclusively women who were patrons. Notably, explicit prostitution was outlawed in Japan in 1958.

\footnotetext{
141 The "younger sister" of a true geisha, or a geisha-in-training.

142 Saburou Osaka, Nanshoku kaidou wo yuku (Ryoki: October 1947): 14.
} 
Life for women in Japan had never been easy. They had always been considered inferior since medieval Japan with Buddhist monks and their preaching, as well as with popular Confucian ideologies where a woman was to serve a man and any other dynamic between male and female was considered unnatural and strange. This social structure existed through wars, and constant government changes, and endures in some forms today. Because Japanese women were considered unequal to men since the medieval period, they never gained the same freedom, choices, or rights that their husbands, brothers, and fathers had. Furthermore, since women were expected to obey, the "pink industry" had a very easy time of targeting females and marketing them for intimate services that even included visual fantasies and deviant sex for men. ${ }^{143}$ The only "sanctioned expression of female sexuality exists within marriage." 144 In other words, women did not, and continue not to, have the freedom to express themselves without harsh judgment, but it was fine for a man to pursue his desires as long as he was responsible about it and did not make a spectacle of himself or his family.

As late as in1983, few women were pursuing high level occupations or an education past high school simply because there was no need for them. Thirty-two percent of Japanese women in that year continued their schooling, but $90 \%$ of that group went only to junior colleges and $22 \%$ actually went to four year universities.

Unfortunately, those women who did obtain a degree from a four year institute did not have higher chances of getting employed. ${ }^{145}$ The working world was and still is considered a "male realm" in Japan. Working women were expected to quit once they

\footnotetext{
143 Allison, 159.

144 Mark McLelland, “The Love Between 'Beautiful Boys' in Japanese Women's Comics.” Journal of Gender Studies 9, no. 1 (2000): 14.

145 Allison, 93.
} 
are married and have children so it is difficult for them to advance due to this expectation from their employers. Furthermore, a working woman is not defined by her career, whereas a working man commits most of his "energy, time, and loyalties" to his job and everything about that is his place in society.

There was one exception to this basic frame for both men and women, and that was prostitution. Employees of the sex industry are considered below everyone else, outcasts, or people who simply do not fit in anywhere else. The biggest reason that host clubs even came into existence is because women also needed a place to relax and to forget about their own realities for at least a little while. And most of the clients of host clubs are women "from pink businesses" ${ }^{146}$ who feel unfulfilled or depressed about their own careers. Therefore, hosts and hostesses created a comfortable partnership with one another, to fill the loneliness caused by not fitting into the culture they were born to.

During the 1980s and 1990s, the red light districts of Japan were dominated by men. In $1997,51.7 \%$ of Japanese men over twenty-five admitted in a survey that they paid for sex or sex related acts. The survey was then broken down into another question: What is the reason for buying sex or sex related acts? $16.4 \%$ were "seeking stimulation", $15.0 \%$ said "desire is only natural," $13.4 \%$ answered "because someone is selling it", and 9.4\% said "because I don't want to destroy my family."147 This is a clear example of how casual or unaccountable men can be about their desires as well as the importance of keeping up social appearances at all costs.

Within the red light districts today, there are countless establishments that offer

146 The Great Happyness Space: Tales of an Osaka Love Thief (2006),DVD, directed by Jake Clennell (Osaka: Jake Clennell Productions, 2006).

147 Mark D. West, Lovesick Japan (Cornell University Press: Ithaca, 2011):147. 
various services. Some shops have themes, from motifs as basic as "royalty" to one bar where leotard-wearing hostesses "drive pudgy executives through taxing fitness workouts." 148 Other clubs are straightforward and strictly business. If there is a red paper lantern hanging outside of the bar, it is a nomiya or a shop that offers drink and food.

Some establishments are completely anonymous, others not so much. It became necessary for all of these businesses to be regulated. In 1948, the Business

Entertainment Control Law (Fuzoku Eigyo Torishimariho) was created. It was amended in 1984, 1998, and 2005, and is still relevant to the nightlife of Japan today. The law not only stipulated how dance clubs and regular bars must be run, but it regulated sex businesses as well. The law does not prohibit these businesses, but they must belong to one of the following categories: 1) Soapland ${ }^{149}$, 2) Fashion health/Cosplay ${ }^{150}$, 3) "Strip clubs" or anywhere that "shows the human form after removal of clothing for the purpose of arousing sexual curiosity," including places a customer can watch DVDs, 4) Deriheru, delivery health services where a woman goes to the customer, 5) Telephone/date clubs wherein men wait for calls from unknown women, approximately $35 \%$ of whom are high school girls, and 6) Imakura (Image clubs), ${ }^{151}$ touch pubs, and pink salons. Any sexual business outside of these limitations would be considered illegal. Furthermore, the Prostitution Prevention Law, article 3 states that "No person shall prostitute or be the client of a prostitute," but violation of this law carries no

148 Bornoff, 226.

149 Soaplands have been around since the banning of prostitution. They skirt around the law by not allowing penetrative sex, and by claiming that it is a business where customers are bathed. A man (or woman) will lie down on a mat, get covered in a lubricant-like substance, and get massaged until orgasm by the female attendant.

150 Cosplay, short for "costume play", is exactly that. It does not always have a sexual connotation but is simply the dressing up as various characters or archetypes (like "maid", "catgirl", and "nurse", for example).

151 Imekura or "image clubs" are establishments with specific themes that often cater to fetishes or kinks. A maid cafe, for example. 
penalty. Most interestingly, these laws all refer to prostitution by women for men, with no other combinations. ${ }^{152}$

In no way does the law deter the sex industry. Most abide by the law but use loopholes to get around the prostitution part. Oral sex, for example, does not count as prostitution. Other times, sexual encounters are handled under the table or the owner of the business will say that whatever happens on an employee's own time is his or her own business. In 2005, 1306 soaplands, 1021 fashion health clubs, 439 strip clubs, 794 telephone clubs, and 25,721 deriheru services were reported. ${ }^{153}$ Today there are thousands of hostess clubs in Tokyo alone.

Because the law for sex business was not written for any homosexual situations, male prostitutes could carry on the tradition as fronting as other professions or places, even though it was by technicality not illegal. Apparently "light entertainment" and "sewing" were the most common fronts for male entertainment, and they, like the inns of the past, looked like "perfectly ordinary hostelries." 154 Today in Kobe, Japan's venerable red-light district of Fukuhara still has clubs that present themselves similarly to the toruko, or Turkish bath style, businesses from their heyday in the past, as well as post-war brothels. ${ }^{155}$ Bathhouses become known as "soaplands" in 1985, after Turkish relations expressed offense in them. The government outlawed the bathhouses, though Japan Bath Association bypassed the law by renaming them. ${ }^{156}$

Outside of host clubs, male services presently include seikan messaaji (sexual massage). This service is, on average, about $\$ 200$ per ten minutes plus hotel charges. 
Men can also be "volunteers", simply offering sex to a client who pays him to perform only that and then leaves. Other exchange types include sharing a meal together before going to a hotel and splitting the tab as the service fee. ${ }^{157}$ The closest thing to being a host is becoming a "call boy" who hangs around in straight or gay hustler bars and is essentially pandered out. Some of his earnings go to the manager of the club he belongs to, and the rest (plus any tip) is for him to keep. These bars are unique in that customers stand on one side while the "boys" stand on the other. An "elderly club manager" goes between the two to set up the meeting. He will nod at an old customer or whisper to the boys, making sure that "everyone is having fun, and keeping a sharp eye out for men who are ready to buy." 158 If the customer is unsatisfied, he can order a chenji (change) and is often guaranteed a replacement within 20 minutes. Clients can also call the hustler bars to order by phone. Client and manager discuss the type of sex that will be had, and also specialties of the club such as S\&M or threesomes. Then the delivery price is given. As an example, Osaka's Date Salon rents out up to 200 boys a night. ${ }^{159}$

Of course, host clubs are classified as pink businesses. They are the most expensive type of entertainment and probably also the least sexual. To avoid legal restrictions, sexual service is often referred to as maruhi ruumu saabisu -- secret room service. Though the host/client relationship can lead to sex, it is considered the "end game" of the relationship, where getting the client to come back more than once is the goal of the business. Although it may seem a difficult task, it is actually not even remotely so. Customers are looking for something that will last. The relationship may be somewhat superficial, but it is better than simply sleeping with a stranger for money one

\footnotetext{
157 West, 152.

158 Constantine, 149-150.

159 Ibid., 152-153.
} 
time or continually finding new partners.

While a hostess is defined as "a woman who, at a cabaret, nightclub, bar, or other facility services and entertains customers for a living," 160 the same definition applies to hosts. At some point, this kind of business stopped being about sex and was much more about simple company. A man paid for an ongoing relationship and not simply a one night stand or even any sex at all. This relationship should sound familiar by now. The taikomochi were entertainers who were hired for the same reason. Men who did not have time for friends and could not confide in their wives in medieval Japan paid for ongoing social interaction.

The appeal of men as customers in hostess clubs is that the hostess is repeatedly put in her place. The men she is serving can lecture her, evaluate and criticize her, anything from her body to her personality and even her life choices, ogle her and paw at her, and she must do as the customer asks. This is the fantasy for many male customers as their wives or girlfriends may not fit into their idea of a perfectly subservient woman. Even with the social traditions as they are, a woman in a real relationship does not completely set her man up on a pedestal while he repeatedly knocks her off of hers. As Anne Allison, who was a hostess herself for a time, put in her book,

men like to be in charge or have the appearance of being in charge; to be the focus of attention or the ones deciding to whom the attention will be directed; to have their words listened to and accepted; and to be generally fussed over, pumped up, complimented, flattered, and indulged. ${ }^{161}$

In a club run by males, females are able to escape their realities too, albeit in a slightly different way. What all customers of host clubs desire, regardless of their gender or the

\footnotetext{
160 West, 165.

161 Allison, 164.
} 
gender of their hosts, is a little romance and a little resting time. The "playacting" that goes on between host and client is all apart of the fantasy too. In fact, stepping into different roles once inside the club adds to the pleasure of the experience as well. ${ }^{162}$

Generally, unless the club has a very specific theme, hosts have the same basic looks. They usually wear expensive suits with equally expensive accessories such as earrings, bracelets, brooches, and rings. Their hairstyle is typically worn a bit long and layered with plenty of gel or hairspray to keep it in sort of a spiky style, and it is very often dyed blond. Many hosts will also wear light make-up such as foundation, eyeliner, and mascara. The reason for their image is that they are much different than the "plain and boring" Japanese salaryman, ${ }^{163}$ and fit into the ideal fantasy for a Japanese woman.

Although host clubs typically have flashy signs or plenty of posters with the faces of their hosts on them, the actual hosts also go out into the street to attract customers. In the documentary "The Great Happiness Space,"164 filmed in 2006, the viewer watches hosts attempt to pull girls in, even out in the rain. Many girls ignore the advances of the hosts or simply try to turn them down and keep walking, though the young men are trained to be very persistent even in the face of rejection. They would use key phrases such as “Aren't you tired?” or complimenting a girl's appearance, or simply asking them directly to hang out with the hosts for at least an hour. Most hosts say that they can tell by what a girl is wearing or carrying whether or not she would be a good customer (or could afford it). Generally, they choose girls in a group or welldressed businesswomen who are walking alone in the evening. As previously

162 Bornoff, 444.

163 The equivalent to the American usage of "businessman". A salaryman is the blanket term for an employee of any large corporate company who works in an office.

164 The Great Happyness Space: Tales of an Osaka Love Thief (2006),DVD, directed by Jake Clennell (Osaka: Jake Clennell Productions, 2006). 
mentioned, however, the most frequent customer for a host is a fellow sex worker. Most often it is hostesses, since they also earn a very high salary, but regular prostitutes, cabaret girls, and soapland girls are also popular.

Once a customer enters the club, she can look through a "menu" of the various hosts. Usually this menu will be in a book or on the wall, sometimes even on a computerized screen. It displays the host's picture, his "work" name, and perhaps his ranking or what "type" of host he is - i.e. - a prince, a bad boy, an ojisan or older man, good at drinking, funny, or so on. The chosen host is the one who will get paid or credited for ranking purposes, even though several hosts may stop by the table over the course of the night. Of course, since more than one customer can usually purchase the same host's time, it becomes something of a competition to keep that host at your table the longest.

Large clubs for hosts and hostesses can seat anywhere from 200-300 people at a time, but most clubs tend to be small, seating only a "handful of customers" in a narrow shop, and "offering a cozy, intimate environment." the club Rakkyo shows that a private seat may be purchased for more money than the base fee for the club. This private seat is hidden from view of the rest of the club and has high walls in order to create an even more quiet atmosphere. The typical seats in a club are cushioned benches or couches arranged around tables. The lights are very often dimmed and there is loud music, singing, shouting, and plenty of flirting.

The main activities in a host club are drinking, making conversation, and sometimes singing karaoke depending on the club. Unlike most karaoke places in Japan,

165 Allison, 37. 
the customer is not offered a private room but rather sings out in the open in the club. All clients must purchase a drink along with the door fee. Drinking goes on from open to close, and hosts often worry about the condition of their livers. Issei from Rakkyo explains in the documentary that in order to consume that much alcohol a night, they would drink some and throw it up so they are able to drink more. It is not a healthy lifestyle as many hosts also smoke and do not get much sleep. However, drinking may be the most important part of a host club from the business perspective. A host's ranking is also contingent on how many bottles of champagne or liquor he sells. Most host clubs have a "keep bottle" system. A member can purchase a bottle of liquor that is then served to him/her during subsequent visits. Expensive bottles are even displayed to show a customer's status. ${ }^{166}$ Even without the "keep bottle" system, some customers buy several bottles of champagne in one visit, and it is usually loudly announced or associated with a game or song from a group of hosts. The reason the alcohol keeps host businesses successful is that it is sold for much more than it is worth. Rather than the alcohol, it is the host serving it that is being sold. Therefore a $\$ 50$ bottle of champagne can easily sell for $\$ 500$, and a $\$ 1000$ bottle can be sold for $\$ 10,000$, just to keep the attention of a favorite host.

Going to a host club is a vicious cycle for the female customers mainly because they feel tired, stressed, or depressed by their sex industry job, so they go to a host club for companionship and relaxation. Host clubs get very expensive, and the only way to pay for the experience is to resort to prostitution. Both men and women in the industry have expressed that they feel trapped in the business, that they will never be able to leave it or get a job in the regular working world. It is a difficult cycle to break because 166 Ibid., 43. 
like any addiction, one begins to crave the escape from work which becomes expensive. The only way to make the large sums of money required to pay for hosts in a short amount of time is often prostitution. The hosts may also become bitter about things like real romance, since they are so used to lying and being lied to by their female customers. For example, he may tell a regular customer that he loves her, but it is a lie. She may then tell him that she loves him and wants to marry him, but then goes to several other host clubs and says the same things to different hosts there. The job makes it difficult for hosts to trust potential romantic partners. Likewise, the working girls who are customers often feel they cannot trust the host either, but it matters less to them because they are paying him to make her feel loved. It may not be real in the long run, but it is for as long as she's at the club. In the sex business, a single night of fantasy romance can be enough for the men and women to get out of bed the next day and go back to their stressful jobs. $^{167}$

So why do young men and women get into the jobs in the first place? They may wander into the occupation due to their habits (prostitution, drugs, gambling). They may not "fit in" with the cultural mold and feel that pink businesses are the only way to live the lifestyle they want. Some become hosts and hostesses because of the very high salary, which would enable them to move on to something else once they have saved enough, or simply enable them to buy fine things. Some men even become hosts simply because they enjoy being with beautiful women all the time.

In the district Nichoume in Tokyo, there are some clubs exclusively for gay men, although host clubs of this nature do not yet have a large presence. Many homosexual

167 The Great Happyness Space 
males work as hosts so that they can get close to other male hosts. Some clubs do service "less common" interests, including cross-dressing clubs. A club recently opened in 2015 in Tokyo, that encourages men who are curious about cross-dressing to come in and try on costumes without judgment. Other examples include Miyazaki, a club in Osaka, and Donguri in Tokyo. At Miyazaki, all the hosts are pudgy men in their 40s, and at Donguri the hosts are aged 50 and up. The customers can fondle the host of their choice, and many such clubs attract younger males who are interested in the oyaji or older male type. ${ }^{168}$

In general, there are three categories of homosexual men. Homo men are regular “straight-looking” males whereas gay men use feminine language, cross-dress, and usually prefer their partners to look and act as straight as possible. The third type is "new half" which is used to describe transgendered individuals. Male-to-female transgender workers often service regular salarymen with "more exotic stimulation." A bar called New Half Monogatari offers $\$ 180$ an hour with its hosts, advertising that "our girls like it from behind." ${ }^{169}$ Likewise, there is also considered to be three categories of customer in the sex club business. The first is "sofuto," soft customers looking for innocent kissing and fondling. Second is "haado," hard customers who patronize gay hotels. Third are the "urutura haado," or ultra hard customers who are seeking anal $\operatorname{sex}^{170}$

It is important to note that clubs and other entertainment industry businesses do not really advertise outside of their respective districts. The internet has opened up an alternative way to reach outside of those districts, even with host databases or official

\footnotetext{
168 Constantine, 165.

169 Ibid., 159-160.

170 Ibid., 150-151.
} 
websites for the clubs. There may even be job advertisements posted on Japanese craigslist or other employment boards. But within Japan itself the businesses and their services stay where they have been assigned. Clients of such businesses keep that part of their lives separate from everything else and will most likely not admit to being a patron of such activities. Where once it was normal to employ a taikomochi or take a kabuki actor home, by the $20^{\text {th }}$ century to present, it is considered unnatural or embarrassing.

Many clubs, regardless of the target audience, do not welcome foreigners because they may not understand the culture and etiquette of a host club. While many foreigners may enter a host club as a joke or "just to try it", it is taken seriously by the hosts and clients who frequent them. Another reason is naturally the language barrier, although there are some hosts who speak English or other languages, or clubs that allow a foreigner in as long as they have a Japanese companion. These factors have also made it more difficult to properly learn about the men in these businesses.

Other club restrictions that possibly affect host clubs, depending on their theme and available services, include some alcohol laws and late-night dance laws that prohibit dancing in public clubs after a certain hour. The "outdated" law is currently being challenged by liberal grassroots campaigns and events in Japan. Two years ago, one was held in Osaka. Kazuo Nakamura, a lawyer and the spokesperson for the June 2012 event, asserts that "laws are modified every year", so changing an old law for entertainment venues should not be difficult. ${ }^{171}$ That is far easier said than done in a very conservative country. However, if dance clubs are able to succeed in getting more freedoms for their businesses, then the road may open to more host-club or sex-specific

171 Mark Jarnes, “Grassroots group forms to fight antidancing law,” Japan Times, June 14, 2012, http://www.japantimes.co.jp/culture/2012/06/14/music/grassroots-group-forms-to-fight-antidancinglaw\#.VDTgbPldWU0 (accessed October 8, 2014). 
changes in Japan too. That is if hosts, hostesses, and their businesses are ever fully acknowledged by the public.

The real world is not the only place where changes have occurred for male entertainers. From the medieval to the Edo eras and beyond, romantic fantasies were written and drawn about males and male love where the audience was primarily other males. By the twentieth century, new stories were being made and told about men (sometimes being together with other men) that catered specifically to women. Fictional fantasies for homosexual males of course also still existed. It is through these stories that the minorities in Japanese society have been able to explore their sexualities where they have otherwise been denied. Even foreigners once thought of Japan as a safe haven for sexuality. Today, Japanese men will, according to Nicolas Bornoff, assume "and not always correctly, that the straight male Westerners have an innate horror of homosexuality," and they will assure the foreigners "that Japan is devoid of such a perversion." But until the mid-1980s, many foreign homosexuals found Japan, with its “colorful and even venerable history [of homosexuality], to be a paradise."172

172 Bornoff, 427. 


\section{CHAPTER FIVE: MEN IN PRINT}

While it was common to buy the company of a man in ancient and modern periods, contemporary Japan has changed its view entirely on male-male relations. Buying fictional material, such as books, comics, or pictures of beautiful or homosexual men is unusual within Japanese society; nonetheless it is still a very prosperous business.

Douseiai novels became popular in the 1910s and 1920s, more than erotic prints or the short stories and limericks of the past. The readers of the narratives were often men who no longer fit into the mold of an acceptable Japanese male, and the books gave them an outlet. They could seek out others like themselves through the narratives. Some fans of same-sex books even suggested "organizations" or "clubs" so that they would have people to talk to or possibly have a relationship with. Although the clubs did not happen until many decades later ${ }^{173}$ the rising popularity of the novels was a start.

Early twentieth century narratives began to involve not just the physical depictions of sex as in the ukiyo-e prints or explicit short stories from the Edo period, but also descriptions of behavior and personalities in the texts. ${ }^{174}$ These are known as "gender roles" today. Due to its long tradition of fully explicit art, Japan "tolerates" erotic materials openly, as long as no adult genitalia is shown. ${ }^{175}$ Although there are laws and restrictions on the production of erotic works, the genre's historical roots help avoid litigation. Furthermore, the pornography industry has helped Japan's economy immensely over the years, so it cannot be completely unacceptable to the government.

173 Pflugfelder, 299.

174 Ibid., 253.

175 Aleardo Zhangellini, "Underage Sex and Romance in Japanese Homoerotic Manga and Anime," Social and Legal Studies 18 (2009): 162. 
Even feminist researchers and anti-pornography advocates have begun to realize the close correlation between the "shadow economy" of pornography and sex work and the mainstream economy of Japan. ${ }^{176}$ The "lolicon" (lolita complex) genre, featuring very young, often under-aged girls, brings in approximately $\$ 3.6$ billion US dollars a year alone, and it is only a small part of Japan's manga economy. ${ }^{177}$ These numbers are extremely helpful with Japan's current economy which many believe is suffering in part due to the family model where the man works and the woman stays home as a housewife.

The genre's success loops back once again to the existence of shuudou and its resulting works of male-male fiction. The male brothel business began to dwindle, but the literary world of douseai continued its operations with very little hindrance. The Prostitution Prevention Law of 1956 was worded in such a way that prostitution's "male forms" were "technically legal in contemporary Japan." ${ }^{178}$ According to Japan's penal code, "even the toughest bouts of homosexual intercourse [cannot] be defined as sex" due to the impossibility of connecting any sex organs. ${ }^{179}$ In fact, the end of World War II and the beginning of the American Occupation had brought about much looser constraints on public representations of sexuality. Contemporary male hustler bars developed after this time, along with red-light dives, shanty-taverns, moonshine taprooms, and female impersonating male hookers. ${ }^{180}$ Danshou, as they were primarily referred to in southern Japan, became especially popular. The term is now considered

176 Sandra Buckley, “The Encyclopedia of Contemporary Japanese Culture”. Taylor \& Francis, 2009: 402.

177 James Fletcher, "Why hasn't Japan banned child-porn comics?" http://www.bbc.com/news/magazine30698640

178 Pflugfelder, 157.

179 Constantine, 157.

180 Ibid., 154. 
discriminatory for the most part, although some older gay men still favor it. ${ }^{181}$ These were men who cross-dressed and attracted Japanese soldiers. Right after the war, the danshou could be found everywhere in large cities. The end of WWII also brought about pink salons which had evolved from otashiki kissa (parlor cafes) that offered drinks, dirty talk, and mutual stimulation. ${ }^{182}$ Men and women both worked as prostitutes in pink salons, with women even invited to move to big cities and stay in a dormitory for a very low price. These salons were known for being the "cheapest, most casual, and most rapid orgasms". They were often loud and musty buildings with rows upon rows of tiny box seats, private compartments for intimate meetings to take place. ${ }^{183}$

By the 1960 s and onward, male prostitution had a regular presence. ${ }^{184}$ Bars opened by the dozens and there was almost 200 of them by 1970. In 1974, the first Japanese gay magazine "Barazoku" published a list of gay hotels, porn shops, and renta-boy bars. ${ }^{185}$ Writers, artists, and business owners got away with much more than they could prior to the Occupation. This is not to say that they were completely unmonitored, “as continued controversy over 'obscene publications' to this day" will prove. ${ }^{186}$ Samesex publications existed freely but were characterized alongside other "perversions," ranging from fetishism, sadomasochism, pygmalionism (the erotic desire for statuary), and metatophism (where the wife becomes the more aggressive partner). ${ }^{187}$

To this day, marketing sexuality in Japan acts as both a danger and a benefit to

181 Hideko Abe, "Queer Japanese: Gender and Sexual Identities Through Linguistic Practices". Palgrave Macmillan, 2010. 13.

182 Constantine, 131.

183 Ibid., 121.

184 Amara Das Wilhelm, "Tritiya-Prakriti: People of the Third Sex: Understanding Homosexuality, Transgender Identity, and Intersex Conditions Through Hinduism". Xlibris Corporation, 2004, 213.

185 Constantine, 155.

186 Pflugfelder, 329.

187 Ibid., 289. 
the political status quo. Although the government would prefer to do away with obscene materials altogether, the pornography business rakes in large sums for the economy and makes itself out to be a "necessary evil". According to Takashi Kanokura, an economist and author, in 2007 the "fashion health" (sexual services including fellatio) business drew in $\$ 8$ billion, and teenage prostitution raked in $\$ 700$ million. ${ }^{188}$ Although it is almost unanimously decided by historians and researchers that statistics are difficult to find, many articles and websites cite FamilySafeMedia.com and toptenreviews.com, both stating that in 2006 Japan's pornography revenues were almost \$20 billion. ${ }^{189}$

To balance this out, the government has placed certain restrictions on pornographic materials. For example, "incredible indulgence" in sexual expression in the media, along with realistic depictions of any part of the genitalia including pubic hair, is "rigourously and consistently outlawed." 190 Also, the Japanese government openly endorses a sexual economy that "evades the state surveillance of public realism and therefore constructs the stimulation and simulation of sexuality as a fantasy nondependent on the graphic or visual display of genitalia." ${ }^{191}$ In other words, as long as there is no sexual depiction of any situation that is too real or may encourage deviant behavior, the government will accept the production of pornography.

Furthermore, prosecutions for obscenity in Japan are very rare. There is a "social preference" in Japan for social harmony, a consensus in the abhorrence of public displays, and avoidance of the loss of face at all costs. That is why rather than prosecuting obscenity, it is better to ignore it. The industry is therefore "largely left to

188 Jake Adelstein. http://www.japansubculture.com/sexnomics-japans-billion-dollar-sex-industry-andthe-pink-zone/

189 http://www.familysafemedia.com/pornography_statistics.html

190 Allison, 155.

191 Ibid., 150. 
regulate itself" ${ }^{\prime 192}$ as long as there is some attempt at censorship. Even in real life situations, very few arrests ever actually occur within red-light districts. In Nichoume, for example, the most common crackdown of a club is due to the employment of underage boys, something the Japanese government takes very seriously, or "Siegfrieds and Adonises", i.e. foreign men, working beyond the provisions of their visa. ${ }^{193}$

One of the biggest and most popular sellers in Japanese media is manga, the "graphic novel" type of books that are known globally. In Japan, there is a manga for every type of person, and one may find anyone from elementary school children to businessmen reading a manga. There are many different genres of manga which include comedy, horror, drama, and even comics specifically catering to males and females. Many fans of manga like it due to the combination of writing and illustrations. Also, Japanese as a language has a propensity for onomatopoeia, which adds a certain degree of aural depth in the story that is lacking in English. ${ }^{194}$ Reading a manga is almost as fulfilling as watching a movie, since it appeals to many senses.

Romance and pornographic manga are extremely popular for all genders, and there are even several sub-types of these manga available, such as hentai or ecchi ${ }^{195}$ manga which is heterosexual pornography, yuri or lesbian relationships, shoujo that is (usually romantic) for girls, and $B L$ or "boy's love," about homosexual love between males. The latter two categories especially will be essential to understanding this paper. The former hostess Anne Allison argues that

in Japan, the consumption of erotic representations that decentre (sic) normative 192 Zhanghellini, 161.

193 Bornoff, 428.

194 Welker, 844.

195 Ecchi, by the way, is literally "H". It is short for hentai and often used to indicate sexual activities or perversions. 
heterosexual adult sex is integral to the maintenance of national values and stability, by creating a safe haven of respectability for adult genitalia and heterosexual intercourse. It is instrumental to national productivity, ${ }^{196}$

The erotic fantasy material, provides people with an outlet for sexual exploration and expression where it may otherwise be thought inappropriate. This is especially true for women and homosexual people who have very little chances for expression or discovery. That is why comics and novels that depict homosexual love or female-centric fantasies are extremely important. These works actually create a world that is safe and free from judgment. Modern Japan may have been mostly tolerant of homosexuality and arguably less homophobic than most Western societies during that time, but contemporary Japan is not. Therefore, one easily finds that in contemporary comics and novels the "assumption that role-structured homosexual activity is a common male experience" is still present. ${ }^{197}$

There is still quite a difference in publications for women and those for men, regardless of the latter's sexual orientation. For example, where girls' magazines such as "June" and "B-Boy" frequently have graphic "sexual interludes," male comics exploit force and violence over all. ${ }^{198}$ This is even different in comics written for gay men, and shouen $a i^{199}$ stories which are mostly written for female readers. Gay magazines tend to portray men as hyper-masculine figures "moving in a strictly homosocial world from which women and their concerns have been banished."200 Okama characters, or feminine, flamboyant gay males are thought to be humorous, or "sad women manque," whereas in media for women, gay feminine men are more positively displayed.

\footnotetext{
196 Zhanghellini, 165.

197 Leupp, 201.

198 McLelland, 19.

199 Lit. "boy love".

200 McLelland, 14.
} 
That is all related to the popular "host" figure in the media targeting girls. Real life hosts and fictional hosts almost play off one another. Men dress more femininely and even wear make-up because it is appealing to women who enjoy feminine males in manga. A storyline may include a dazzling host because it is a popular character type for males and represents the kind of man that Japanese girls express desire to be with romantically. Furthermore, these hyper-masculine males in gay magazines are also written as "sex maniacs." In women's comics, there is a sense of mutual exchange that lacks in comics written for men. ${ }^{201}$ Even though the subject matter is similar, their content is very different. All explicit comics with male characters share something in common, the censorship. Since the mangaka (artist) cannot draw an actual penis, the genitals are usually symbolized by items such as baseball bats, swords, beer bottles, even something like a carrot. They may also be "censored" by placing thin bars over certain parts of the genitalia, though the lines seldom cover up what it is. They still fall within the censorship laws. Some authors skirt the laws by simply erasing the genitals and leaving an open, implied space.

Why are comics revolving around male sexuality and male love so important for the young female readership? The answer is that it is not the male characters that women are interested in, but the stories and the fantasies woven into them, where they can imagine a romance that is either a) their ideal heterosexual romance that they cannot get due to the gender inequality, or b) an ideal romance they can imagine safely between two men because the genders represented separate them from reality. These romance comics allow women to dream of a different life without directly associating the stories with themselves and risking social embarrassment.

201 Ibid., 15-16. 
Admittedly there are different scholarly opinions on this matter. Many scholars believe that "Princess Knight" (Ribon no Kishi) by the famous Japanese mangaka Tezuka Osamu spawned the shoujo manga genre as well as the subgenre of boy's love. ${ }^{202}$ Whether or not that was true, "Princess Knight" was one of the first and did pave the way for other shoujo dream tales. It showed that a woman had the power to manipulate male characters. She could reconfigure the "male identity in terms of female desires," and take on the role of "doer," which was very empowering. ${ }^{203}$ Before the 1970 s when Tezuka Osamu wrote his works, this notion was hardly even conceived or thought possible. Due to social conditioning, shoujo manga readers could not "positively accept their own sexuality as women." 204 Pleasure had always been about the man's desires and needs and the only "sexuality" a woman had was defined by her marriage. But "Princess Knight" began a revolution, allowing females to gain a voice within a patriarchal world.

The twist in the BL genre, then, also comes from the strong patriarchal presence in Japanese culture. These stories of male-male romance liberate the reader from those social confines, gender dualism, and heteronormativity. Homosexual love between men also strengthen the fantasy because only men can love men as a complete equal. Women and young boys are often exploited within adult male fantasy, which is expressed through violence, power, and control. But two adult men can be equals. What is more, the love between two adult males will not result in pregnancies or only "loving them [the partner] as wives" the way it can be between a man and his female lover. Such a result is very unromantic in Japan. Contemporary women are straying further and

\footnotetext{
202 Welker, 846.

203 Mark McLelland and Seunghyun Yoo, “The International Boys' Love Fandom and Implications of Current Legislation,” Sexual Research and Social Policy: Journal of NSRC 4, no. 1 (2007): 99.

204 Welker, 842.
} 
further from the expectations placed on them by antiquated traditions. By reading a BL story, they can see the only relationship free to love beyond the constraints placed on them by society. It may be an escape from reality, but within a society that is resistant against change, it is sometimes the best solution to an unhappy place in society.

The switch from male to female readers of these types of narratives began in the 1970s, and already by the early-mid-1980s the "world of Shinjuku Nichoume" became revealed to women. They were learning about a "world full of beautiful boys" like those in "the world of shoujo manga" and were finding freedom in the expression of it. ${ }^{205}$ The fantasies and desires surrounding pretty males and homosexuality never disappeared from the early nanshoku lifestyle or emaki prints. Neither did purchasing the company of a man. It simply evolved into a new, thriving kind of expression for the "outcasts" of Japan.

205 Welker, 857. 


\section{CHAPTER SIX: BOYS' LOVE}

"Regardless of whether boys' love manga were created merely to offer heterosexual readers a temporary respite from patriarchal restrictions on their desire, some readers found in identifying with the beautiful boy a way through the looking glass to a world outside the patriarchy." 206

Humans have always found escape in fictional worlds, much like they can find an escape from reality in visiting host clubs. From the beginning, paying for a man's company, whether he was a taikomochi or a common prostitute, has always been an escape from reality. Reading erotic texts or looking at erotic pictures of "pretty" men has always been for indulging one's fantasy. The most "extensive representations of homosexuality in Japan" now "exist in comics directed at young women."207 What once was strictly for pleasure now serves as much more to its consumers.

The BL genre is often referred to also as yaoi, which is a Japanese acronym for "no buildup, no foreclosure, and no meaning." 208 Although Boys' Love and yaoi are often mistaken, especially from a Western standpoint, as being the same thing, they are not. ${ }^{209}$ While they both depict homosexual men, they are seldom treated as the same. Yaoi is "porn without plot", often more hardcore and fetishist. BL has more of a "plot" and is far more similar to a shoujo manga in structure and character development.

It is also interesting to note that, although Nichoume in Shinjuku is a place targeting gay males, and there are now internet forums and other outlets where gay men

206 Ibid., 865.

207 McLelland, 13.

208 Zanghellini, "Boys' love in anime and manga: Japanese subcultural production and its end users," 279.

209 The writer of the article "Boys' love in anime and manga: Japanese subcultural production and its end user", Aleardo Zanghellini, claims that fans of "yaoi" and "BL" treat them as a single genre. I disagree. 
can speak out in Japan, BL manga is targeted elsewhere and commonly thought by the actual gay community to be a "distorted representation." 110

Lesbians and "beautiful boys" are "narrative outlaws" in Japan. They invite the violation of patriarchal law with regard to love, gender, sex, and sexuality. BL and shoujo also offer a "safe haven where [readers] can experiment with identity, find affirmation, and develop the strength necessary to find others like themselves, and a sense of belonging." ${ }^{211}$ This is exactly why these fictional books and comics are so important in Japanese culture. With the genre of Boys' Love alone bringing in approximately 11.9 billion yen in the manga industry a year, ${ }^{212}$ it is safe to say that it will not be going anywhere anytime soon. Conservative Japan has become so oppressive for women that many regard the comics they read as a message space. It doubles over as entertainment too, of course.

Female artists began to write about love between boys when "contrived and formulaic" heterosexual love stories marketed at girls became largely disappointing and boring to them. ${ }^{213}$ They were beginning to conform to gender roles, the marriage system, the end goal of the female to produce and raise children, which has steadily fallen from the female interest. Women and girls are more interested in getting an education or a solid career. Keiko Takemiya's “In the Sunroom” (Sanruumu nite) in 1970, and Tezuka Osamu's "Princess Knight" are also credited as being the beginning of the BL genre. Both mangaka are pioneers of their respective genres. Perhaps it is most fair to say that

210 Zanghellini, "Boys' love in anime and manga: Japanese subcultural production and its end users," 160. 211 Welker, 865-66.

212 Febriani Sihombing, "On the Iconic Difference Between Couple Characters in Boys Love Manga" Image and Narrative 12, no.1 (2001): 150.

213 Zanghellini, "Boys' love in anime and manga: Japanese subcultural production and its end users,", 279. 
Osamu's works opened up the world of shoujo, and Takemiya's works that of BL.

Many of Keiko Takemiya's works are set in European-like fantasy worlds. She illustrated how borrowing visually and culturally helped to liberate the readers and writers from their own realities, to work within and against the "local heteronormative paradigm" in the exploration of alternatives. ${ }^{214}$ After the 1970s, BL texts changed their representation of male-male sex, and it was no longer the "ends in themselves," 215 but merely a natural part of the story, as if the relationship was entirely expected and natural.

The BL genre of today relies on "well-established romance scripts" 216 to tell its stories, often conforming to certain archetypes. Like the samurai and their younger companions, as well as the priest-acolyte relationship, there is usually a hierarchical relationship within a BL manga, and the partners often have an age difference. Romance between schoolboys is also very common, however, so there are clearly not strict guidelines to writing a BL story either. Perhaps this is why these stories never "bore" readers, the possibilities are endless. Also linking back to its predecessors in the past, BL "reworks" the myth of "unmatchable femininity" that was found in the onnagata actors of kabuki theater. ${ }^{217}$ Like the female-role actors of Edo Japan, the characters of a BL work are more beautiful than women, thus further playing into the fantasy aspect of it. There is even a sort of model for which role the "beautiful boy" plays in the BL manga. Boys with black hair are typically the more masculine active partner in the

\footnotetext{
214 Welker, 841.

215 Zanghellini, "Boys' love in anime and manga: Japanese subcultural production and its end users,", 286.

216 Ibid., 284.

217 Zang, 169.
} 
relationship, whereas boys with "white" 218 or lighter hair are usually more passive, drawn as much more visibly feminine. There are many exceptions to this, such as the author Naono Bohra's works, which often portray the older, dark haired male as the passive role. Nevertheless, it is a recognizable ingredient in many BL tales. Finally, BL manga draws from its predecessors of the past in which the dominant character very often vows to always protect the passive character, the antecedent to this being the vows between samurai brothers and priests with their acolytes. ${ }^{219}$ All of these traits are very commonly adapted as host personas and styles that male escorts use. The difference is that girls are seldom stopped from enjoying a manga about a host but would be shamed for going to a club in reality.

The plot of a BL story, or a shoujo one, for that matter, varies just as much as any genre of fiction. It may be set within high school life or the teachers there, salarymen, outer space, or imaginary fantasy lands with royal courts. Of course, one very popular theme is the host club. Many manga have a character working directly as a host or a "pretty boy" in a club somewhere in Tokyo, as is featured in Kano Miyamoto's works. Other plotlines are more subtle about the "host style" within, featuring a character with bleached hair and a lot of jewelry who intimidates other characters because he looks "like a host". Some make a complete twist on hosts and do not even focus on the thin line between host clubs and prostitution, such as the internationally popular series "Ouran High School Host Club", which is about a group of "pretty boys" with very different personality tropes who form a host club within their high school. These representations are generally very positive toward hosts and men in pink businesses,

\footnotetext{
218 With the exception of covers or color spreads, manga are almost always black and white.
} 219 Zang, 170. 
which is very interesting considering the negative feelings directed at real life hosts. A fictional host is far more likely to be acknowledged than a real one, most likely because of the freedom that fiction gives to its Japanese audience.

Artists like Takemiya "mentally liberated" girls from the restrictions "imposed on" their sexuality, ${ }^{220}$ and soon more and more artists followed. These expressive graphic novels expose readers to sex and sexuality without making them actual participants in anything. It is desire and romance that are the focus of boys' love narratives too, rather than just something explicit and sexual. Of course this is very much like what hosts represent to women. It is not the sex but the bond they form with this otherworldly, beautiful man.

So why not write narratives for girls that are about girls? This too is another social construct put on women raised in a misogynistic culture. This self-effacing, mental conditioning extends even into the literary world. Moto Hagio, another pioneer in shoujo and BL manga like Osamu and Takemiya, once wrote two versions for her manga. The first was a male-male and the second was a female-female. It was the former that she published, saying in an interview that she "found her girl-girl romance

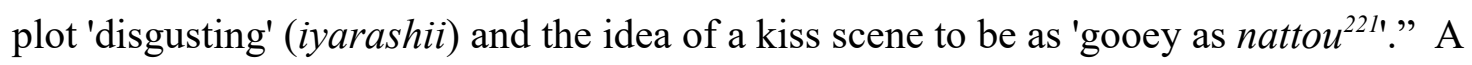
male-male story, venturing into the "unknown world of [a] boys' school is more interesting," she goes on to say. ${ }^{222}$ Generally, male homosexuality is widely more tolerated than lesbianism. In Japanese media, lesbianism is practically invisible 223 despite there being a time in the 1920 s where romance between school girls was

220 Welker, 855.

221 fermented soy bean paste

222 Welker, 858.

223 McLelland, 18. 
popular. Similarly to hints of a homosexual history, female romance is merely covered up and forgotten. Writing about men is simply safer.

Feminist scholar Chizuko Ueno adds that "the beautiful boy is the graphic embodiment of the girls' idealized self-image." Whether that is true or not, it is certainly buyable, with the long eyelashes, smooth, slender bodies, and feminine features that men in shoujo and BL manga have. According to Welker, some even see beautiful boys as "sexless" despite all of the sex some of them have. He also believes that reading "him" as a boy in a shoujo or BL tale is an "active choice" the reader can make ${ }^{224}$. But there is little evidence of completely viewing a male character as a female or "actively" choosing how to refer to him. Many readers of manga do not want that close of an association with the characters. Some fans of BL are perfectly content leaving romance between two males, and in fact Japanese girls are shown to be more accepting of homosexuality than boys are. This is likely because both females and homosexuals are oppressed by their culture.

What really gives Boys' Love its freedom is that the gender of its main audience "unsettles assumptions made by policy makers, law enforcement, and legal officials about the [dangers] of works of the imagination." 225 These policy makers and so on do not quite know what to make of the female interest in fictional works about men, just as women being served by men confuses them as well. Also, the genre in all its popularity has become something of a threat. The phenomenon behind Boys' Love is that it is a female gendered space. Manga of all types is sold everywhere from convenient stores to specialized stores. BL manga is also openly sold in designated sections of every

\section{Welker, 852.}

225 Zanghellini, "Boys' love in anime and manga: Japanese subcultural production and its end users,", 282. 
bookstore. The business claims female writers, artists, editors, and readers. It has become so profitable it has joined many other professions of today in providing thousands of jobs for women that "enable them to be economically independent"226 from men. This is a huge development for a conservative Japan that stubbornly stays conservative despite most of the world around it changing. It is certainly a threat to what the government believes is a stable system, and proof that that system is, in fact, losing its ability to influence the people.

The increasing amount of male-run host clubs and homosexual clubs - Nichoume boasts at least 300 clubs today 227 - is also proof that the people want things to change. With younger generations growing up and having so much access to news, media, and pop culture from all over the world, they are slowly gaining footing in creating a more up-to-date society despite everything being thrown against them. There is still a long road ahead for sexual freedom in Japan, but a formidable obstacle has still been cleared.

226 McLelland, Yoo, 96.

227 Bornoff, 427. 


\section{CHAPTER SEVEN: CONCLUSION}

The Japanese government is compelled to support the sex industry because recreational sexuality sustains work relations. ${ }^{228}$ However, the government is still hard pressed to accept that it is a part of Japanese culture, and always has been. There is also nothing the government can do about the women's comic genres being "everything Japanese society is not" ${ }^{\prime 22}$, since the industry completely follows the legal guidelines it has been given.

Being a fan of BL manga or a patron of a host club or male-based nightclub is still considered a bit of a weak fight due to the shame still attached to enjoying them. Aleardo Zanghellini, in his study of yaoi manga, states that "fans of all ages appear proud to openly declare their yaoi/BL mania,"${ }^{, 230}$ but this is simply not true. This would be more appropriate to say of Western fans, and even then there is a fair amount of social embarrassment behind openly admitting to being a fan. In Japan, a fan that is too obsessed or involved with whatever it is they are a fan of is considered an otaku. In America this word has been taken, the meaning shifted to something that many anime and manga fans believe to be a positive title. In Japan, however, being labeled as an otaku is a very negative thing. It suggests there is something unnatural about the person's love, which is often clumped together with other psychological social disorders. Similarly, just as in the past, there is a social stigma in openly admitting to spending frequent time in the red light districts. Many people also still have a sense of uneasiness when it comes to host men, as their looks and behaviors can be quite eccentric and usual

228 Allison, 154

229 McLelland, 23.

230 Zanghellini, "Boys' love in anime and manga: Japanese subcultural production and its end users,", 292. 
even without adding the fact that they are sex workers.

As my work has shown, however, these outlets of sexual and social expression have always been present in Japan in some form. It is very easy to see if one simply puts all the history together. Yet, the arts and talents of the taikomochi are seldom mentioned, forgotten by all who want even a summary of history about Japan or the geisha. When studying emaki and wood block prints from Edo, they are almost always supplemented with works that show women as the subservient party to men and men's desires. There is more weight in the history of homosexuality within the samurai culture. However, it is never linked as something that continues in various forms today.

The Japan of the twenty-first century is prejudiced against homosexuals and other minorities. The general belief toward homosexuals is that they should "at least tactfully conceal their sexual preference from relatives and co-workers." ${ }^{231}$ Anyone who is openly gay faces institutional discrimination and general scorn from their families, coworkers, classmates, and so on. Nanshoku is no longer celebrated in the arts but ignored.

The government prefers to pretend that nanshoku and homosexual people do not and did not ever exist. Any mention of homosexuality or nanshoku and it will be discouraged "as one of the 'evil customs' of the past." The blame has also been cast onto the rest of the world, saying homosexuality is "a national embarrassment given attitudes in the modern West,"232 despite taikomochi, priest-acolyte bonds, and samurai all existing before the West was ever introduced into Japan.

This is a part of the world that truly does stand voiceless within its own country. Homosexuality may yet still find representation and acceptance in Japan in the future.

231 Mainichi Daily News (Tokyo: Feb. 14, 1991): 12.

232 Leupp, 204. 
However, such a fate for nanshoku, host clubs, or any kind of "unusual" entertainment job, comes out as extremely bleak. Prostitution never has a good name in any culture regardless of its acceptance.

When surveyed on culture and sex in Japan, the Japanese insist that 'cculturally' the mizushobai (sex work) [is] not a factor at all in the 'essence' of Japanese behavior."233 It may never be considered such. But as history will tell, pretending that something does not exist does not ever truly make it go away.

233 Allison, 11. 


\section{BIBLIOGRAPHY}

\section{BOOKS}

Allison, Anne. Nightwork: Sexuality, Pleasure, and Corporate Masculinity in a Tokyo Hostess Club. Chicago: University of Chicago Press, 1994.

Bornoff, Nicholas. Pink Samurai: Love, Marriage, and Sex in Contemporary Japan. New York: Pocket Books, 1991.

Chambers, Veronica. Kickboxing Geisha. New York: Free Press, 2007.

De Mente, Boyé Lafayette. Sex and the Japanese: The Sensual Side of Japan. Tokyo, Japan: Tuttle Publishing, 2006.

Downer, Leslie. Geisha: The secret history of a vanishing world. London: Headline Book Publishing, 2000.

Ejima, Kiseki. "Nihon meicho zenshuu." 9 vols. Tokyo: Nihon meicho zenshuu kankoukai, 1926-1929: 619.

Gottlieb, Nanette and Mark McLelland. Japanese Cybercultures. Edited by Nanette Gottlieb and Mark McLelland. London: Routledge, 2003.

Kaempfer, Engelbert. The History of Japan Together with a Description of the Kingdom of Siam, 1690-92. Translated by J.G. Scheuchzer. Glasgow: James MacLehose and Sons, 1906.

Kobayashi, Takeshi. Ukiyoe. Tokyo: Kodansha International, 1982.

Leupp, Gary P. Male Colors: The Construction of Homosexuality in Tokugawa Japan. Berkeley, CA: University of California Press, 1995.

Nishiyama, Matsunosuke et al. (eds). Edo-gaku jiten, 2nd ed. Tokyo: Kôbunsha, 1994.

Osaka, Saburou. Nanshoku kaidou wo yuku.Japan: Ryoki, 1947.

Pflugfelder, Gregory M. Cartographies of Desire: Male-Male Sexuality in Japanese Discourse 1600-1950. Berkeley, CA: University of California Press, 1999.

Sawada, Junjirou. Seiyoku hanzai. Kindai no Kekkonsha, 1923.

Schalow, Paul Gordon. "Male Love in Early Modern Japan: A Literary Depiction of the 'Youth'," in Hidden From History: Reclaiming the Gay and Lesbian Past. Edited by Martin Duberman, Martha Vicinus, \& George Chauncey, New York: New American Library, 1989, 118-128.

Sinclair, Joan. Pink Box: Inside Japan's Sex Clubs. New York: Harry N. Abrams, inc., 2006.

Suzuki, Katsutada. Senryuu Zappai kora mita Edo shomin fuuzoku. Tokyo: Yuuzankuku, 1978. 
Takeyama, Akiko. "Commodified romance in a Tokyo host club," in Genders, Transgenders and Sexuality in Japan. Edited by Mark Mclelland and Romit Dasgupta New York: Routledge, 2005, p. 200-215.

Watanabe, Tsuneo and Junichi Iwata. the love of the samurai: a thousand years of Japanese homosexuality. Translated by D.R. Roberts. London: GMP Publishers, Ltd., 1989.

West, Mark D. Lovesick Japan. Ithaca, NY: Cornell University Press, 2011.

Yanagidara, Yakou. "Yanaibako," Shodui Senryuu Senkushuu, 34. Quoted in Gregory M. Pflugfelder. Cartographies of Desire: Male-Male Sexuality in Japanese Discourse 1600-1950. Berkeley, CA: University of California Press, 1999.

Yazaki, Takeo. Social Change and the City in Japan: From the Earliest Times through the Industrial Revolution. Tokyo: Japan Publications, 1938.

\section{JOURNALS}

McLelland, Mark J. “The Love Between 'Beautiful Boys' in Japanese Women's Comics.” Journal of Gender Studies 9, no. 1 (2000): 14-25.

McLelland, Mark J and Seunghyun Yoo. "The International Boys' Love Fandom and the Implications of Current Legislation." Sexual Research and Social Policy: Journal of NSRC 4, no. 1 (2007): 93-104.

Sihombing, Febriani. "On the Iconic Difference between Couple Characters in Boys Love Manga.” Image and Narrative 12, no. 1 (2001): 150-165.

Welker, James. 'Beautiful, Borrowed, and Bent: 'Boys' Love' as Girls' Love in Shôjo Manga." Journal of Women in Culture and Society 31, no.3 (2006): 841-870.

Zanghellini, Aleardo. "Boys love in anime and manga: Japanese subcultural production and its end users." Journal of Media and Cultural Studies 23, no. 3, (June 2009): 279-294.

Zanghellini, Aleardo. "Underage Sex and Romance in Japanese Homoerotic Manga and Anime.” Social and Legal Studies 18 (2009): 159-177.

\section{DOCUMENTARY}

The Great Happyness Space: Tale of an Osaka Love Thief (2006). DVD. Directed by Jake Colnnell. Osaka, Japan: Jake Colnnell Productions, 2006. 


\section{ONLINE}

Jarnes, Mark, “Grassroots group forms to fight antidancing law.” Japan Times, June 14, 2012.

http://www.japantimes.co.jp/culture/2012/06/14/music/grassroots-groupforms-to-fight-antidancing-law\#.VDTgbPldWU0 (accessed October 8, 2014).

Tofugu. "Japan's Fantasy Girls - Geisha to Maid Cafes.” July 27, 2010. http://www.tofugu.com/2010/07/27/japans-fantasy-girls-geishato-maid-cafes/ (accessed March 6, 2013).

The Democratic Part of Japan. Our Basic Philosophy - Building a Free and Secure Society -. http://www.dpj.or.jp/english/about us/philosophy.html (accessed March 16, 2013).

House of Councilors in the National Diet of Japan. The Constitution of Japan. http://www.sangiin.go.jp/eng/law/index.htm (accessed March 16, 2013).

\section{NEWSPAPER}

Mainichi Daily News, February 14, 1991, Tokyo, Japan, page 12. 